\title{
LEVEL II SCOUR ANALYSIS FOR BRIDGE 8 (ATHETH00090008) on TOWN HIGHWAY 9, crossing BULL CREEK, ATHENS, VERMONT
}

U.S. Geological Survey Open-File Report 97-818

Prepared in cooperation with

VERMONT AGENCY OF TRANSPORTATION

and

U.S. Department of the Interior

U.S. Geological Survey

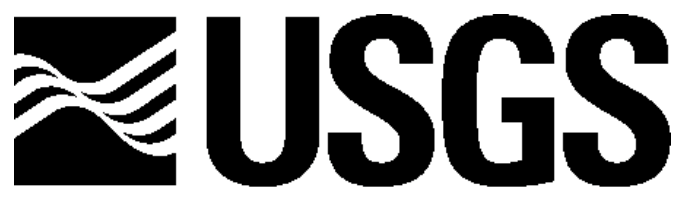




\section{LEVEL II SCOUR ANALYSIS FOR BRIDGE 8 (ATHETH00090008) on TOWN HIGHWAY 9, crossing BULL CREEK, ATHENS, VERMONT}

By ERICK M. BOEHMLER AND RONDA L. BURNS

U.S. Geological Survey Open-File Report 97-818

Prepared in cooperation with

VERMONT AGENCY OF TRANSPORTATION and

FEDERAL HIGHWAY ADMINISTRATION 


\title{
U.S. DEPARTMENT OF THE INTERIOR BRUCE BABBITT, Secretary
}

\author{
U.S. GEOLOGICAL SURVEY \\ Mark Schaefer, Acting Director
}

For additional information write to:

District Chief

U.S. Geological Survey 361 Commerce Way

Pembroke, NH 03275-3718
Copies of this report may be purchased from:

U.S. Geological Survey

Branch of Information Services

Open-File Reports Unit

Box 25286

Denver, CO 80225-0286 


\section{CONTENTS}

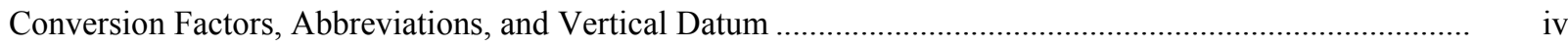

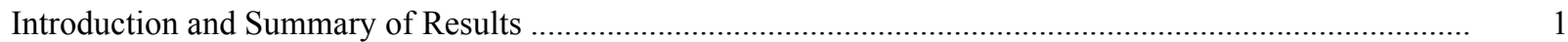

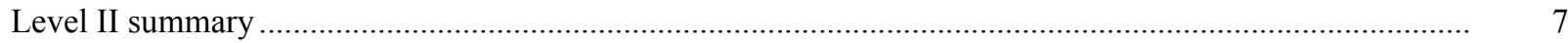

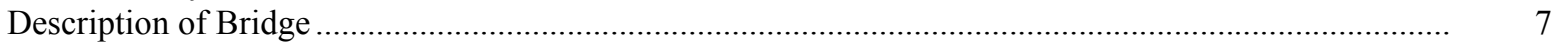

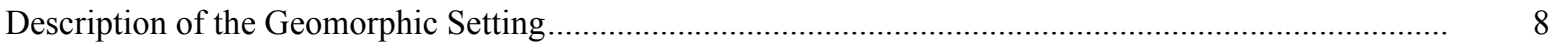

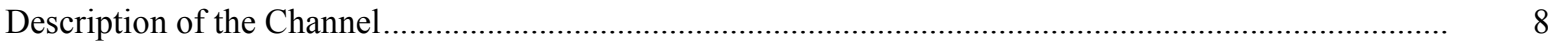

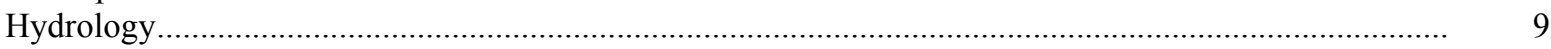

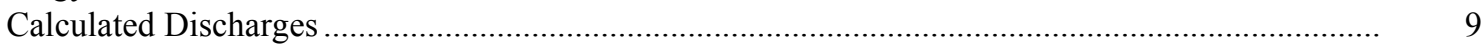

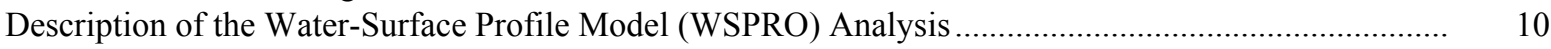

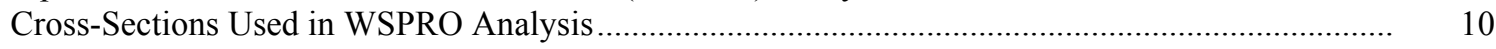

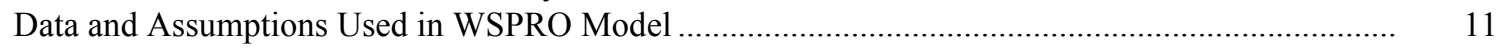

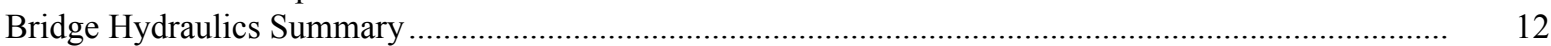

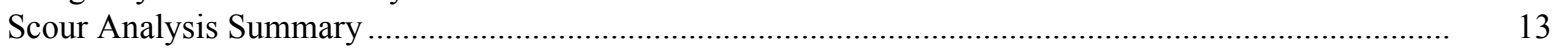

Special Conditions or Assumptions Made in Scour Analysis .................................................... 13

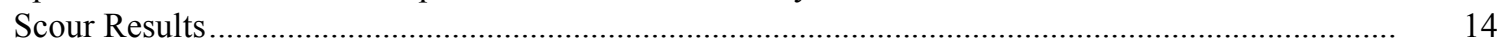

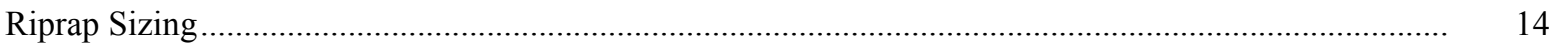

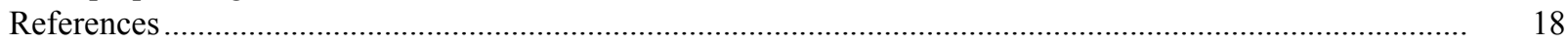

Appendices

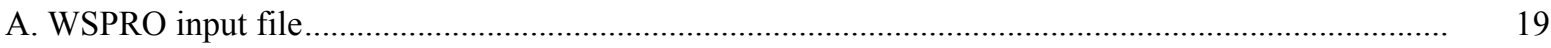

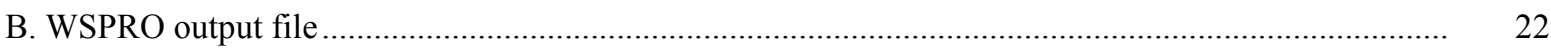

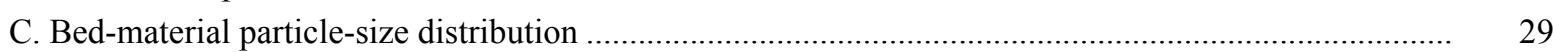

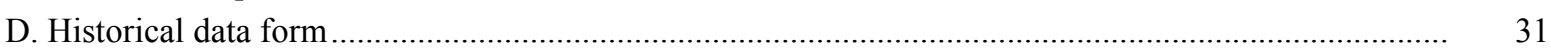

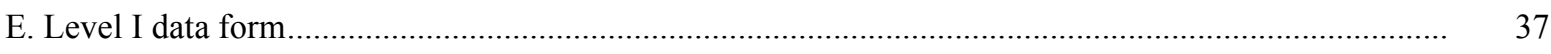

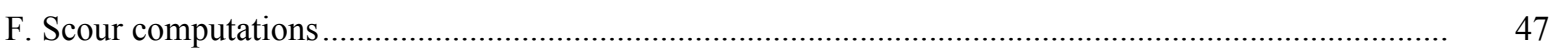

\section{FIGURES}

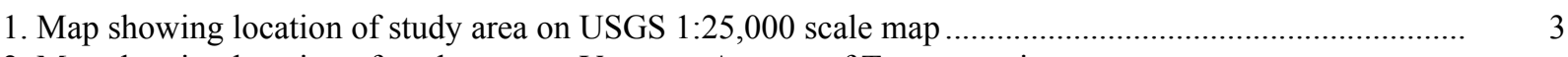

2. Map showing location of study area on Vermont Agency of Transportation town

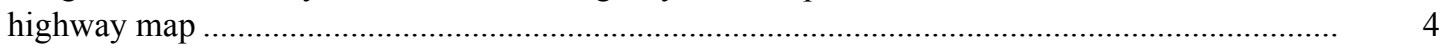

3. Structure ATHETH00090008 viewed from upstream (August 14, 1996) ........................................... 5

4. Downstream channel viewed from structure ATHETH00090008 (August 14, 1996). ............................ 5

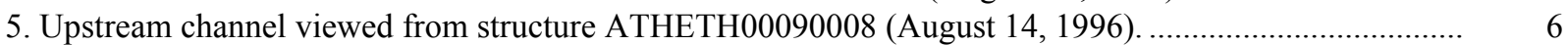

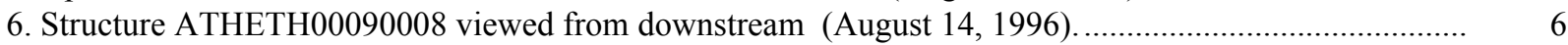

7. Water-surface profiles for the 100- and 500-year discharges at structure

ATHETH00090008 on Town Highway 9, crossing Bull Creek,

Athens, Vermont.

8. Scour elevations for the 100- and 500-year discharges at structure

ATHETH00090008 on Town Highway 9, crossing Bull Creek,

Athens, Vermont.

\section{TABLES}

1. Remaining footing/pile depth at abutments for the 100-year discharge at structure

ATHETH00090008 on Town Highway 9, crossing Bull Creek,

Athens, Vermont

2. Remaining footing/pile depth at abutments for the 500-year discharge at structure

ATHETH00090008 on Town Highway 9, crossing Bull Creek,

Athens, Vermont 


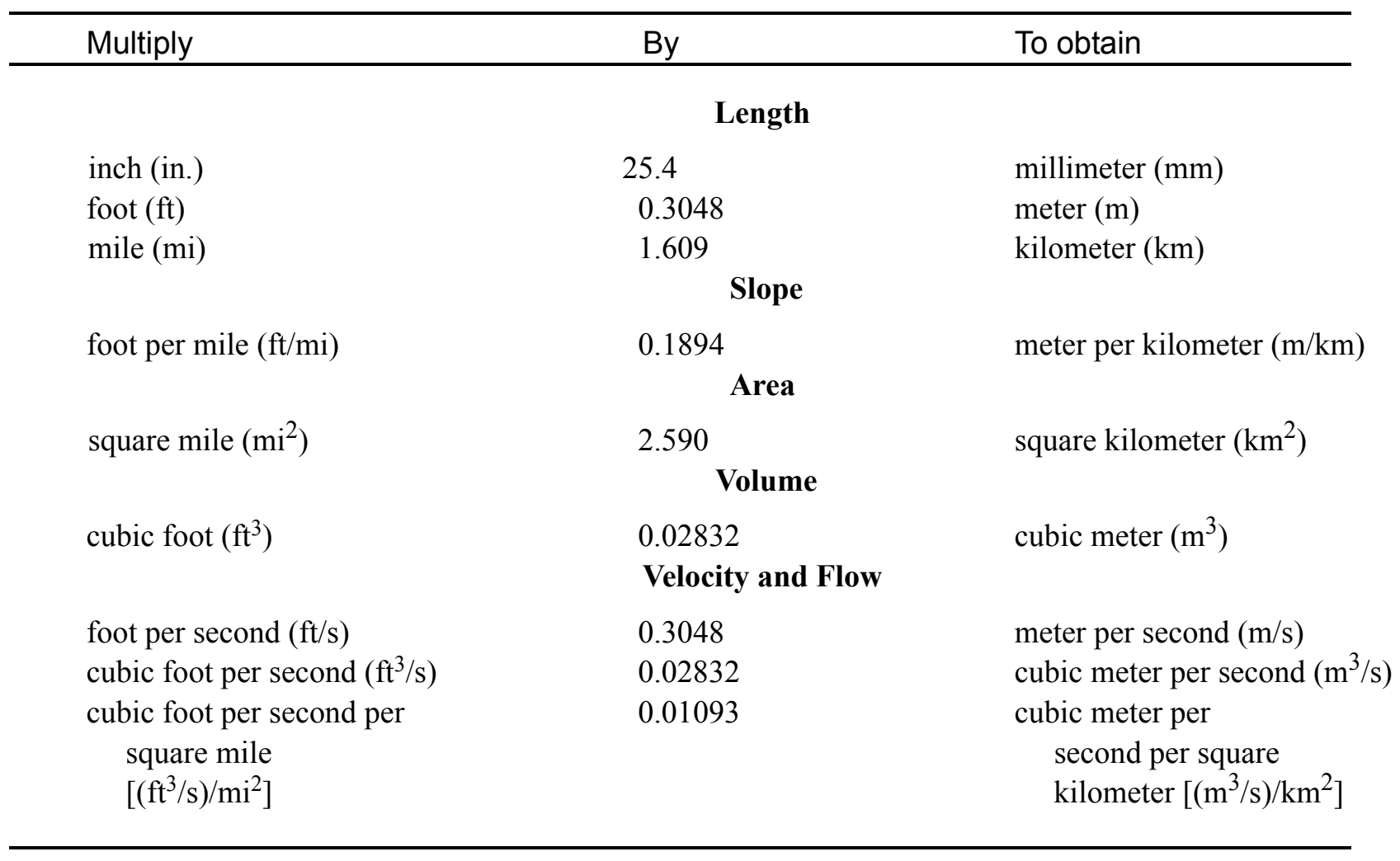

\section{OTHER ABBREVIATIONS}

$\begin{array}{lrlr}\mathrm{BF} & \text { bank full } & \text { LWW } & \text { left wingwall } \\ \mathrm{cfs} & \text { cubic feet per second } & \text { MC } & \text { main channel } \\ \mathrm{D}_{50} & \text { median diameter of bed material } & \text { RAB } & \text { right abutment } \\ \mathrm{DS} & \text { downstream } & \text { RABUT } & \text { face of right abutment } \\ \mathrm{elev} & \text { elevation } & \text { RB } & \text { right bank } \\ \mathrm{f} / \mathrm{p} & \text { flood plain } & \text { ROB } & \text { right overbank } \\ \mathrm{ft}^{2} & \text { square feet } & \text { RWW } & \text { right wingwall } \\ \mathrm{ft} / \mathrm{ft} & \text { feet per foot } & \text { TH } & \text { town highway } \\ \mathrm{JCT} & \text { junction } & \text { UB } & \text { under bridge } \\ \mathrm{LAB} & \text { left abutment } & \text { US } & \text { upstream } \\ \mathrm{LABUT} & \text { face of left abutment } & \text { USGS } & \text { United States Geological Survey } \\ \mathrm{LB} & \text { left bank } & \text { VTAOT Vermont Agency of Transportation } \\ \mathrm{LOB} & \text { left overbank } & \text { WSPRO } & \text { water-surface profile model }\end{array}$

In this report, the words "right" and "left" refer to directions that would be reported by an observer facing downstream. Sea level: In this report, "sea level" refers to the National Geodetic Vertical Datum of 1929-- a geodetic datum derived from a general adjustment of the first-order level nets of the United States and Canada, formerly called Sea Level Datum of 1929.

In the appendices, the above abbreviations may be combined. For example, USLB would represent upstream left bank. 


\title{
LEVEL II SCOUR ANALYSIS FOR BRIDGE 8 (ATHETH00090008) ON TOWN HIGHWAY 9, CROSSING BULL CREEK, ATHENS, VERMONT
}

\author{
By Erick M. Boehmler and Ronda L. Burns
}

\section{INTRODUCTION AND SUMMARY OF RESULTS}

This report provides the results of a detailed Level II analysis of scour potential at structure ATHETH00090008 on Town Highway 9 crossing Bull Creek in Athens, Vermont (figures 1-8). A Level II study is a basic engineering analysis of the site, including a quantitative analysis of stream stability and scour (U.S. Department of Transportation, 1993). Results of a Level I scour investigation also are included in Appendix E of this report. A Level I investigation provides a qualitative geomorphic characterization of the study site. Information on the bridge, gleaned from Vermont Agency of Transportation (VTAOT) files, was compiled prior to conducting Level I and Level II analyses and is found in Appendix D.

The site is in the New England Upland section of the New England physiographic province in southeastern Vermont. The $9.04-\mathrm{mi}^{2}$ drainage area is in a predominantly rural and forested basin. In the vicinity of the study site, the left overbank surface cover is shrub and brushland and the right overbank surface cover is pasture.

In the study area, Bull Creek has an sinuous channel with a slope of approximately $0.01 \mathrm{ft} /$ $\mathrm{ft}$, an average channel top width of $41 \mathrm{ft}$ and an average bank height of $4 \mathrm{ft}$. The predominant channel bed materials are cobbles and gravel with a median grain size $\left(\mathrm{D}_{50}\right)$ of $72.1 \mathrm{~mm}(0.236 \mathrm{ft})$. The geomorphic assessment at the time of the Level I and Level II site visit on August 14, 1996, indicated that the reach was laterally unstable. There are several point bars and cut banks along the reach in the vicinity of this site.

The Town Highway 9 crossing of Bull Creek is a 32-ft-long, one-lane bridge consisting of one 28-foot steel-beam span (Vermont Agency of Transportation, written communication, April 5, 1995). The bridge is supported by vertical, "laid-up" stone abutments with concrete caps and no wingwalls. The channel is skewed approximately 15 degrees to the opening. The VTAOT bridge records indicate the opening-skew-to-roadway is 9 degrees while that computed from surveyed points is 5 degrees. 
A scour hole 1.75 feet deeper than the mean thalweg depth was observed under the bridge during the Level I assessment. The scour hole has lowered the streambed along the entire length of the left abutment and the upstream end of the right abutment. The scour depth at each abutment wall is 0.75 feet deeper than the mean thalweg depth elsewhere in the reach. The only scour protection measure at the site was type- 2 stone fill (less than 36 inches diameter) on the upstream banks and downstream left bank. Additional details describing conditions at the site are included in the Level II Summary and Appendices D and E.

Scour depths and recommended rock rip-rap sizes were computed using the general guidelines described in Hydraulic Engineering Circular 18 (Richardson and others, 1995). Total scour at a highway crossing is comprised of three components: 1) long-term streambed degradation; 2) contraction scour (due to accelerated flow caused by a reduction in flow area at a bridge) and; 3 ) local scour (caused by accelerated flow around piers and abutments). Total scour is the sum of the three components. Equations are available to compute depths for contraction and local scour and a summary of the results of these computations follows.

Contraction scour for all modelled flows ranged from 0.0 to 1.4 feet. The worst-case contraction scour occurred at the incipient-overtopping discharge of 1730 cubic feet per second, which was less than the 100-year discharge. Abutment scour ranged from 7.6 to 11.4 feet. The worst-case abutment scour occurred at the 500-year discharge. Additional information on scour depths and depths to armoring are included in the section titled "Scour Results". Scoured-streambed elevations, based on the calculated scour depths, are presented in tables 1 and 2. A cross-section of the scour computed at the bridge is presented in figure 8. Scour depths were calculated assuming an infinite depth of erosive material and a homogeneous particle-size distribution.

It is generally accepted that the Froehlich equation (abutment scour) gives "excessively conservative estimates of scour depths" (Richardson and others, 1995, p. 47). Usually, computed scour depths are evaluated in combination with other information including (but not limited to) historical performance during flood events, the geomorphic stability assessment, existing scour protection measures, and the results of the hydraulic analyses. Therefore, scour depths adopted by VTAOT may differ from the computed values documented herein. 


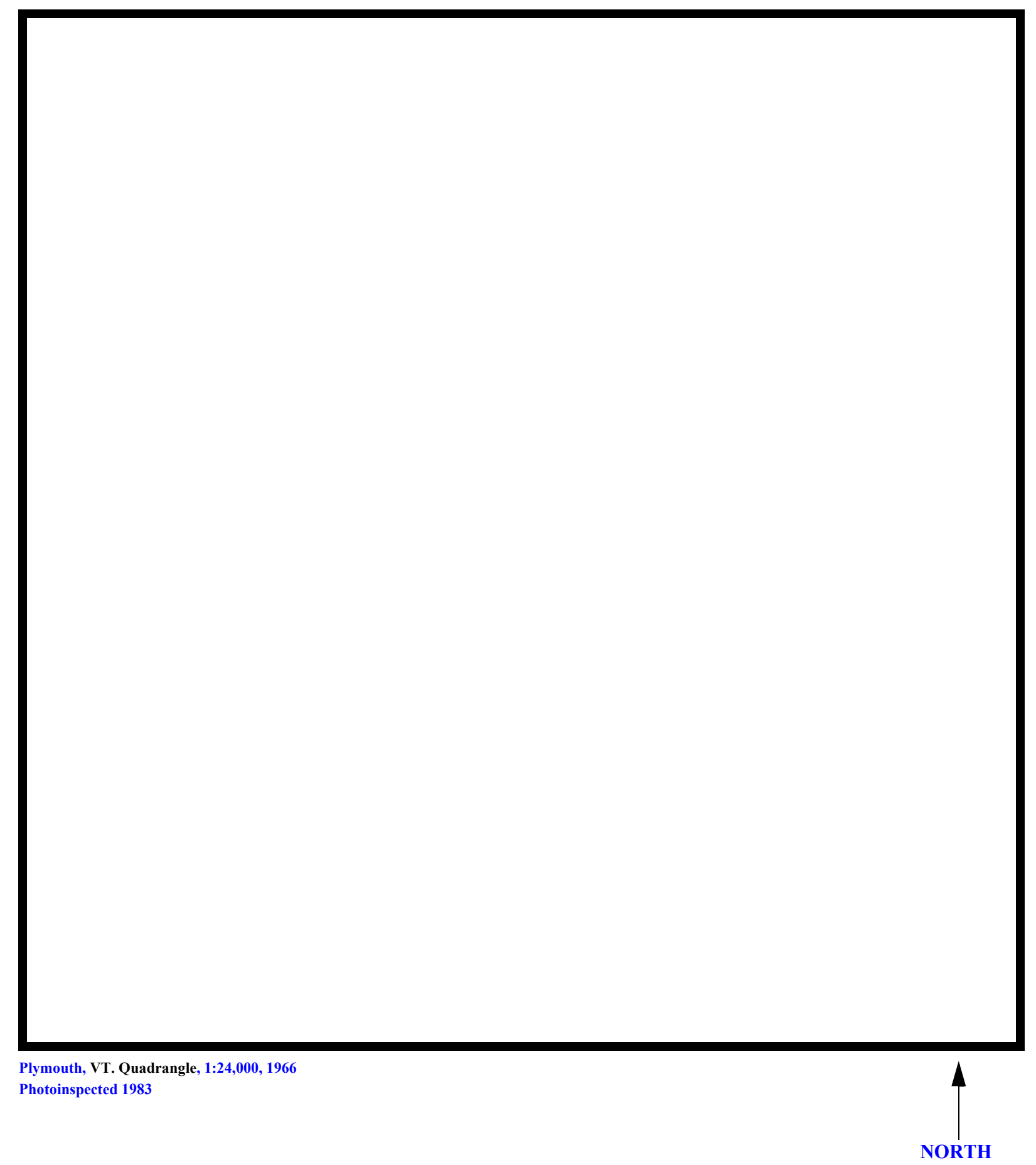

Figure 1. Location of study area on USGS 1:24,000 scale map. 
Figure 2. Location of study area on Vermont Agency of Transportation town highway map. 

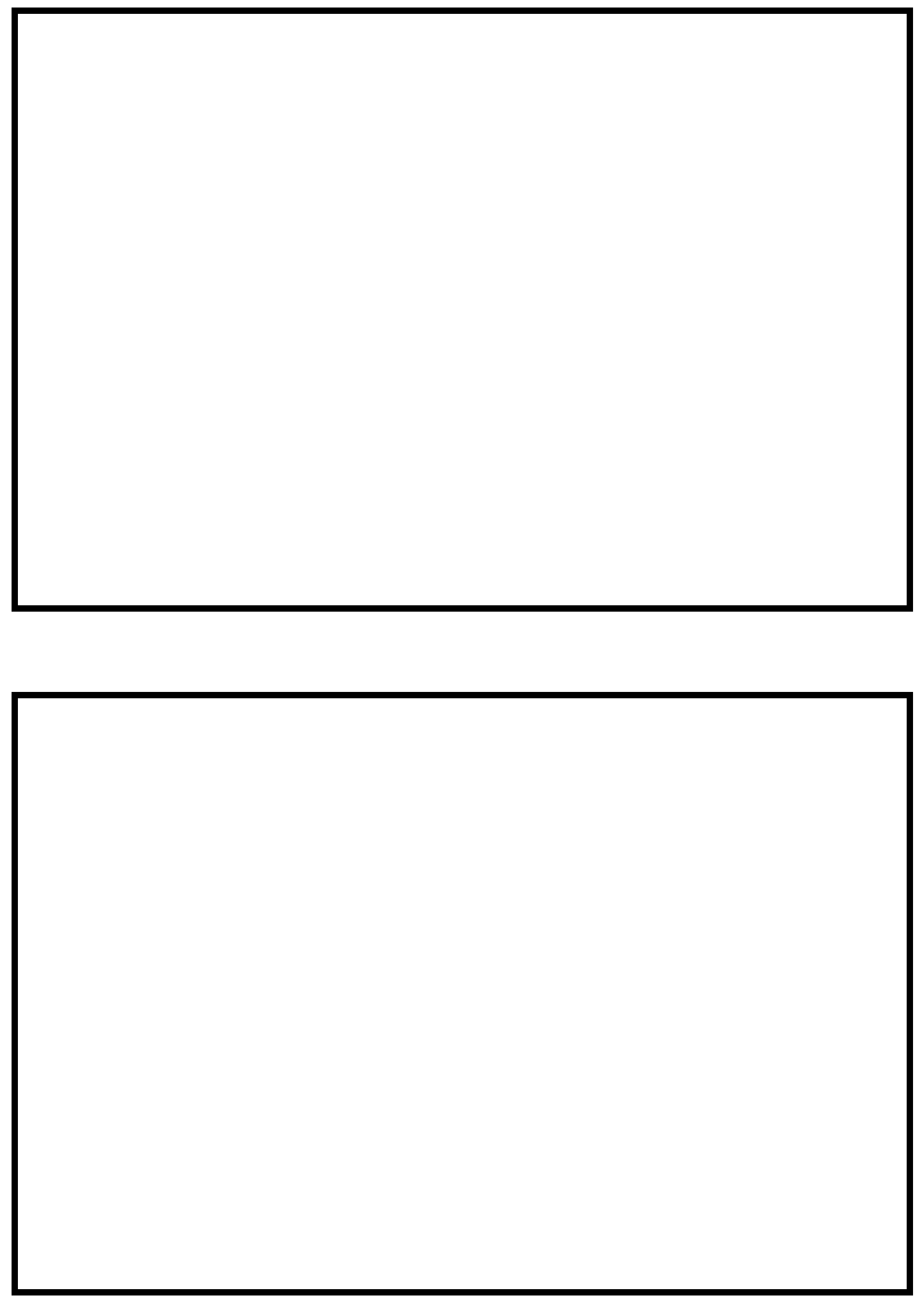

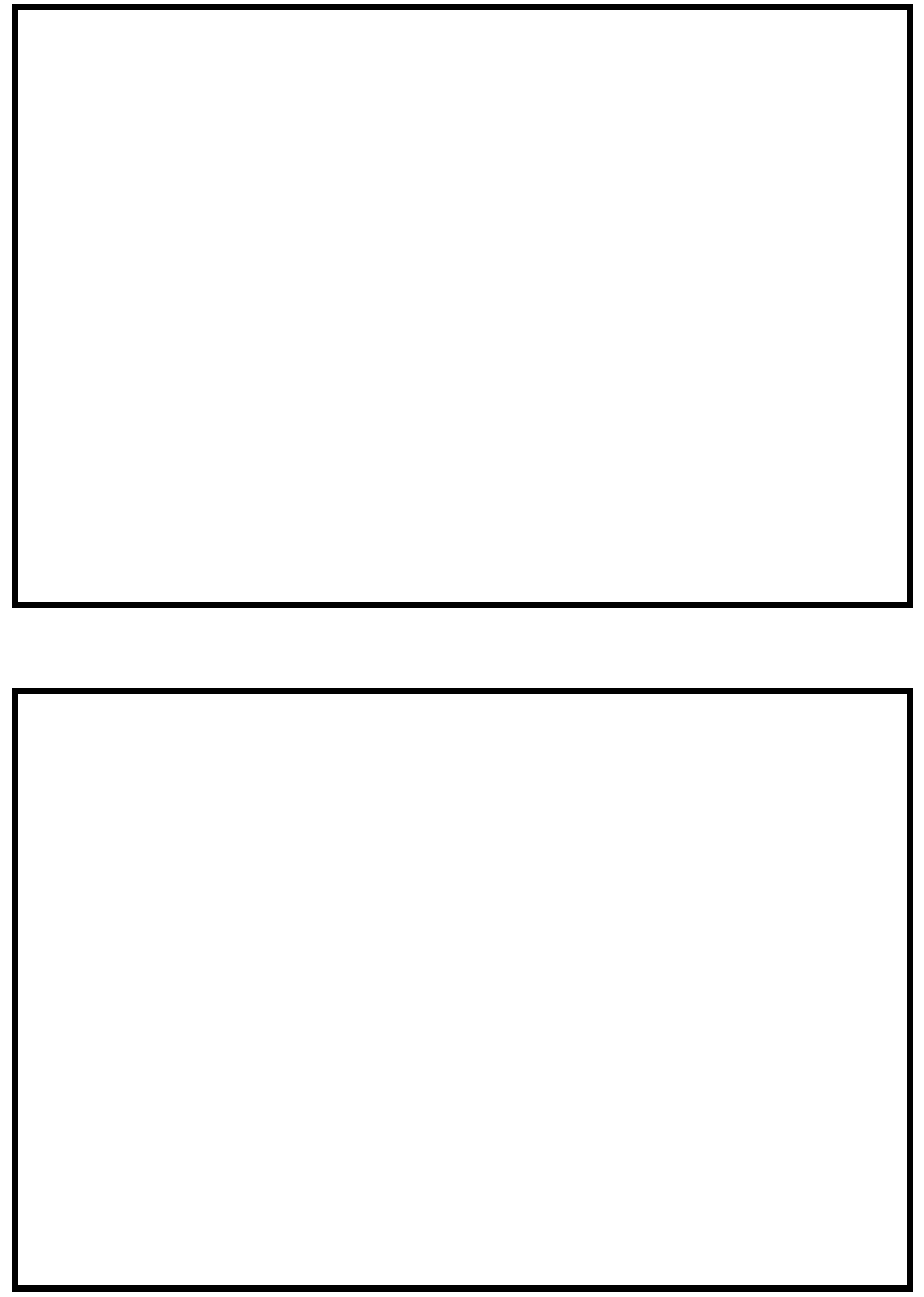


\section{LEVEL II SUMMARY}

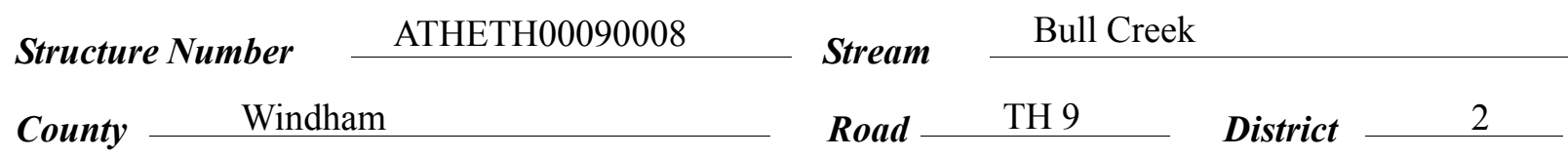

\section{Description of Bridge}

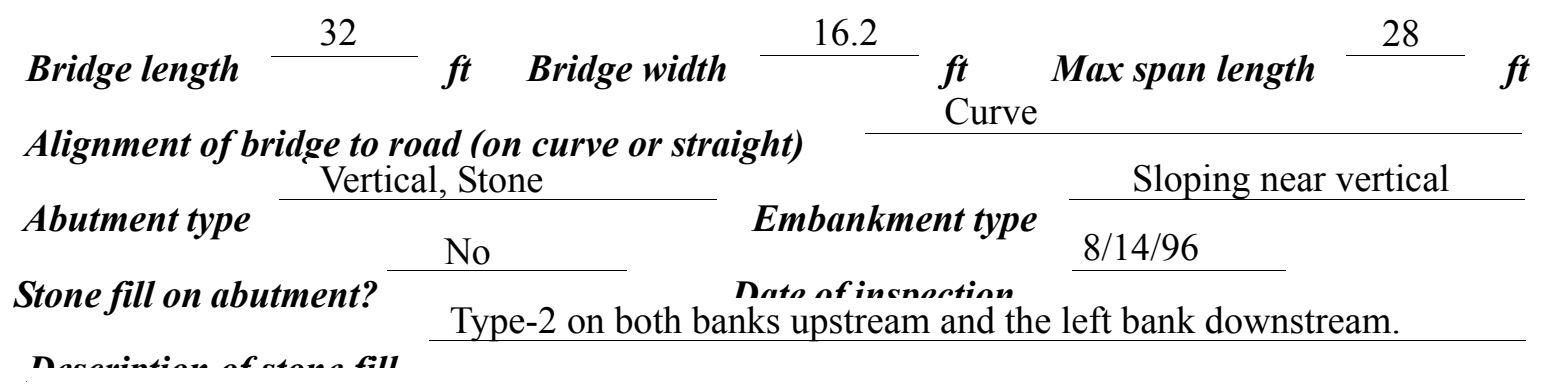

Abutments are non-mortared stone slab walls with

concrete caps. There is a 0.75 to 1.75 foot deep scour hole under the bridge.

Is bridge skewed to flood flow according to Yes 'survey? Angle

There is a moderate bend in the reach through the bridge. There also is an abrupt shift in the channel to the left between 30 and 15 feet upstream of the bridge.

Debris accumulation on bridge at time of Level I or Level II site visit:

Date of insnortion $8 / 14 / 96$

Level I

$$
8 / 14 / 96
$$

Yes
15

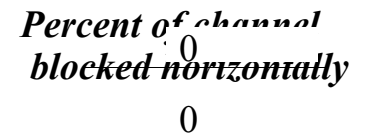

Percent of a n we
blocked verticatty

0

Level II

Moderate. There are some trees and other vegetation on both banks upstream and the channel is laterally unstable.

Potential for debris

As noted on 8/14/96, the roadway embankment to the right abutment blocks the right half of the Doscriho anv fonturos noar ar at tho hridoo that mav affort flow, (includo ohsorvation dato) upstream channel and redirects flow to the left up to bank full stage. 


\section{Description of the Geomorphic Setting}

General topography The channel is located in a moderate relief valley setting with an irregular flood plain and moderately sloping valley walls on both sides.

Geomorphic conditions at bridge site: downstream (DS), upstream (US)

Date of inspection $\quad 8 / 14 / 96$

DS left: $\quad$ Moderately sloping channel bank and valley wall.

DS right: $\quad$ Mildly sloping channel bank and a narrow, irregular flood plain.

US left: $\quad$ Mildly sloping channel bank and a narrow overbank.

US right: $\quad$ Steep channel bank and a wide, irregular flood plain.

\section{Description of the Channel}

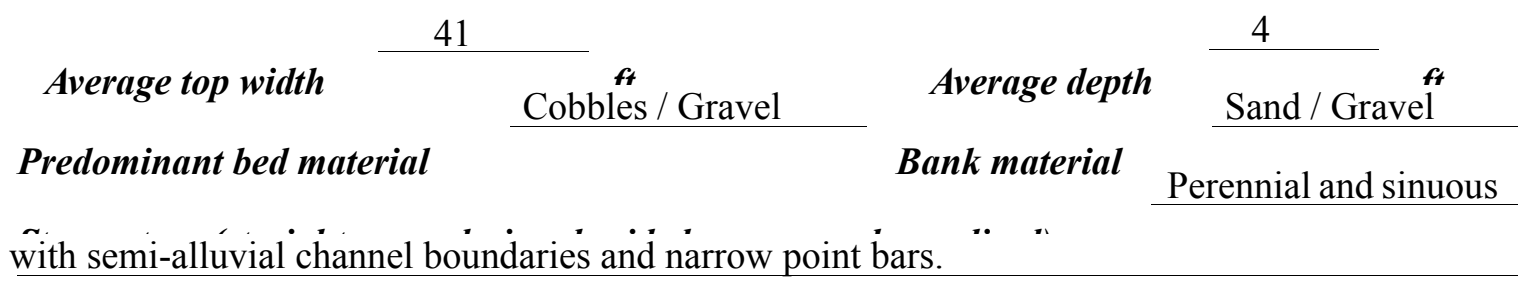

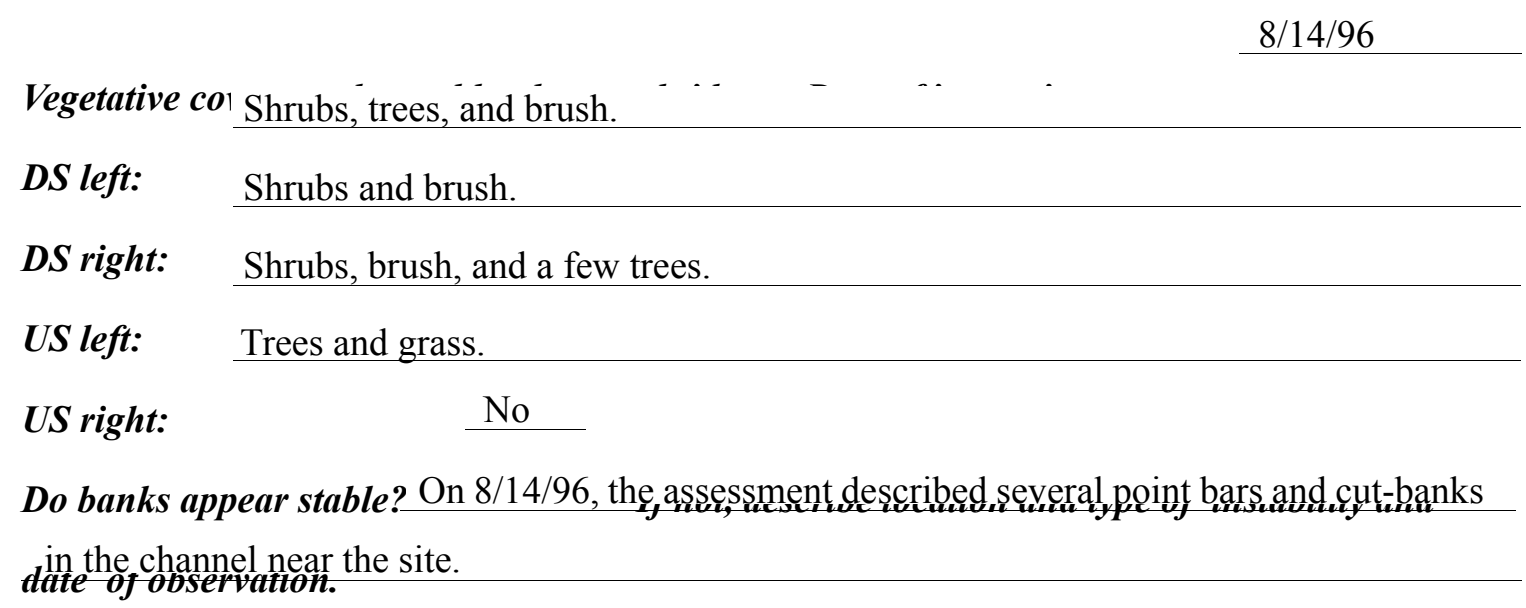

The assessment of

$8 / 14 / 96$ noted a protruding roadway embankment to the right abutment and a moderate bend left Describe any obstructions in channel and date of observation.

in the channel immediately upstream of the bridge. This roadway embankment severely blocks

and redirects flow to the left below bank full stages. 


\section{Hydrology}

Drainage area $\stackrel{9.04}{\mathrm{mi}^{2}}$

Percentage of drainage area in physiographic provinces: (approximate)

Physiographic province/section New England / New England Upland
Percent of drainage area 100
Is drainage area considered rural or urban?
Rural urbanization:
Describe any significant

\section{Calculated Discharges $\quad \underline{3,000}$ \\ Q100 $\quad \mathrm{ft} / \mathrm{s} \quad \mathrm{Q500} \quad \mathrm{ft} / \mathrm{s}$}

The 100- and 500-year discharges were based on a

flood frequency curve computed by use of the Federal Highway Administration (FHWA, 1983) empirical equation. The Federal Highway Administration curve was within a range of empirical flood frequency curves computed by use of other empirical methods and extrapolated to the 500year discharge (Benson, 1962; Johnson and Laraway, unpublished draft, 1972; Johnson and Tasker, 1974; Potter, 1957a\&b; Talbot, 1887). 


\section{Description of the Water-Surface Profile Model (WSPRO) Analysis}

Datum for WSPRO analysis (USGS survey, sea level, VTAOT plans)

USGS survey

Datum tie between USGS survey and VTAOT plans

None

Description of reference marks used to determine USGS datum. $\quad$ RM1 is a chiseled " $X$ "

in the concrete cap of the right abutment at the upstream end (elev. 501.14 feet, arbitrary survey

datum). RM2 is a chiseled " $\mathrm{X}$ " in the concrete cap of the left abutment at the downstream end

(elev. 501.63 feet, arbitrary survey datum).

\section{Cross-Sections Used in WSPRO Analysis}

\begin{tabular}{cccl}
\hline${ }^{1}$ Cross-section & $\begin{array}{c}\text { Section } \\
\text { Reference } \\
\text { Distance } \\
(\text { SRD) } \text { in feet }\end{array}$ & $\begin{array}{c}{ }^{2} \text { Cross-section } \\
\text { development }\end{array}$ & \multicolumn{1}{c}{ Comments } \\
\hline EXITX & -28 & 1 & Exit section \\
FULLV & 0 & 5 & $\begin{array}{l}\text { Downstream Full-valley } \\
\text { section (Bridge channel } \\
\text { points and exit overbank } \\
\text { points) }\end{array}$ \\
BRIDG & 0 & 1 & $\begin{array}{l}\text { Bridge section } \\
\text { Road Grade section }\end{array}$ \\
RDWAY & 8 & 1 & $\begin{array}{l}\text { Modelled Approach sec- } \\
\text { tion (Templated from } \\
\text { APTEM) }\end{array}$ \\
APTEM & 41 & 2 & $\begin{array}{l}\text { Approach section as sur- } \\
\text { veyed (Used as a tem- } \\
\text { plate) }\end{array}$ \\
\hline
\end{tabular}

${ }^{1}$ For location of cross-sections see plan-view sketch included with Level I field form, Appendix E.

For more detail on how cross-sections were developed see WSPRO input file. 


\section{Data and Assumptions Used in WSPRO Model}

Hydraulic analyses of the reach were done by use of the Federal Highway Administration's WSPRO step-backwater computer program (Shearman and others, 1986, and Shearman, 1990). The analyses reported herein reflect conditions existing at the site at the time of the study. Furthermore, in the development of the model it was necessary to assume no accumulation of debris or ice at the site. Results of the hydraulic model are presented in the Bridge Hydraulic Summary, Appendix B, and figure 7.

Channel roughness factors (Manning's " $n$ ") used in the hydraulic model were estimated using field inspections at each cross section following the general guidelines described by Arcement and Schneider (1989). Final adjustments to the values were made during the modelling of the reach. Channel " $n$ " values for the reach ranged from 0.040 to 0.045 , and overbank " $n$ " values ranged from 0.050 to 0.070 .

Normal depth at the exit section (EXITX) was assumed as the starting water surface. This depth was computed by use of the slope-conveyance method outlined in the user's manual for WSPRO (Shearman, 1990). The slope used was $0.0096 \mathrm{ft} / \mathrm{ft}$, which was estimated from the topographic map (U.S. Geological Survey, 1984).

The surveyed approach section (APTEM) was moved along the approach channel slope $(0.0325 \mathrm{ft} / \mathrm{ft})$ to establish the modelled approach section (APPRO), one bridge length upstream of the upstream face as recommended by Shearman and others (1986). This location also provides a consistent method for determining scour variables.

For the incipient-overtopping discharge, WSPRO assumes critical depth at the bridge section. A supercritical model was developed for this discharge. After analyzing both the supercritical and subcritical profiles, it was determined that the water surface profile passes through critical depth within the bridge opening. Thus, the assumption of critical depth at the bridge is a satisfactory solution. 


\section{Bridge Hydraulics Summary}

\begin{tabular}{lll} 
Average bridge embankment elevation & 501.4 \\
\cline { 3 - 3 } Average low steel elevation & 498.9 & $\boldsymbol{f t}$
\end{tabular}

100-year discharge $\quad 2,160 \quad \mathrm{ft}^{3} / \mathrm{s}$

Water-surface elevation in bridge opening $\quad 498.0 \quad f t$

Road overtopping? ___ Yes Discharge over road __ $1360 \quad \mathrm{ft}^{3} / \mathrm{s}$

\begin{tabular}{llll} 
Area of flow in bridge opening & $153 \quad \mathrm{ft}^{2}$ \\
\cline { 2 - 3 } Average velocity in bridge opening & 5.3 & $\mathrm{ft} / \mathrm{s}$
\end{tabular}

$\begin{array}{lll}\text { Maximum WSPRO tube velocity at bridge } & 6.7 & \mathrm{ft} / \mathrm{s}\end{array}$

Water-surface elevation at Approach section with bridge 499.1

Water-surface elevation at Approach section without bridge $\quad 497.6$

Amount of backwater caused by bridge

1.5 it

500-year discharge $\quad 3,000 \quad \mathrm{ft}^{3} / \mathrm{s}$

Water-surface elevation in bridge opening $\quad 498.3 \mathrm{ft}$

Road overtopping? ___ Yes Discharge over road _ $2130 \quad \mathrm{ft}^{3} / \mathrm{s}$

Area of flow in bridge opening $\quad 160 \quad \mathrm{ft}^{2}$

Average velocity in bridge opening $5.4 \mathrm{ft} / \mathrm{s}$

Maximum WSPRO tube velocity at bridge $\quad 7.0$ _s

Water-surface elevation at Approach section with bridge 499.5

Water-surface elevation at Approach section without bridge $\quad 497.9$

Amount of backwater caused by bridge 1.6 .t

Incipient overtopping discharge $\quad 1,730 \quad \mathrm{ft}^{3} / \mathrm{s}$

Water-surface elevation in bridge opening 497.1 it

Area of flow in bridge opening $\quad 131 \quad \mathrm{ft}^{2}$

Average velocity in bridge opening $\quad 13.2 \mathrm{ft} / \mathrm{s}$

Maximum WSPRO tube velocity at bridge $16.6 \mathrm{ft} / \mathrm{s}$

Water-surface elevation at Approach section with bridge

Water-surface elevation at Approach section without bridge

Amount of backwater caused by bridge $\quad 3.7$.t

501.0

497.3 


\section{Scour Analysis Summary}

\section{Special Conditions or Assumptions Made in Scour Analysis}

Scour depths were computed using the general guidelines described in Hydraulic Engineering Circular 18 (Richardson and others, 1995). Scour depths were calculated assuming an infinite depth of erosive material and a homogeneous particle-size distribution. The results of the scour analysis are presented in tables 1 and 2 and a graph of the scour depths is presented in figure 8 .

All of the modeled discharges resulted in free-surface flow through the bridge. Contraction scour for each discharge modeled was computed by use of the Laursen clearwater contraction scour equation (Richardson and others, 1995, p. 32, equation 20).

Abutment scour for the left abutment was computed by use of the Froehlich equation (Richardson and others, 1995, p. 48, equation 28). Variables for the Froehlich equation include the Froude number of the flow approaching the embankments, the length of the embankment blocking flow, and the depth of flow approaching the embankment less any roadway overtopping.

Scour at the right abutment was computed by use of the HIRE equation (Richardson and others, 1995, p. 49, equation 29) because the HIRE equation is recommended when the length to depth ratio of the embankment blocking flow exceeds 25 . The variables used by the HIRE abutment-scour equation are defined the same as those defined for the Froehlich abutment-scour equation. 


\section{Scour Results}
100-yr discharge 500-yr discharge
Incipient overtopping (Scour depths in feet)

Contraction scour:

Main channel

Live-bed scour

Clear-water scour

Depth to armoring

Left overbank

Right overbank

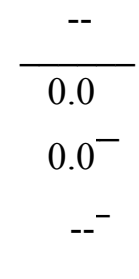

$---$

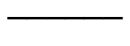

Local scour:

Abutment scour

Left abutment

Right abutment

Pier scour

Pier 1

Pier 2

Pier 3
9.9

7.6-
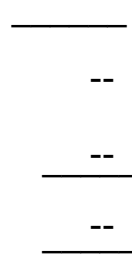

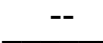

11.4

8.3-

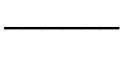

$-$
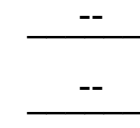

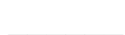

\section{Riprap Sizing}

Abutments:

Left abutment

(D) in feet)

100-yr discharge 500-yrdischarge discharge

Incipient overtopping

Right abutment

Piers:

Pier 1

Pier 2

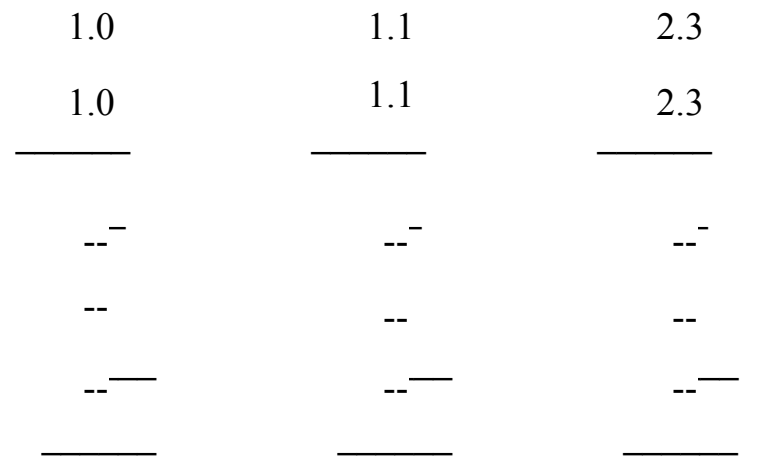




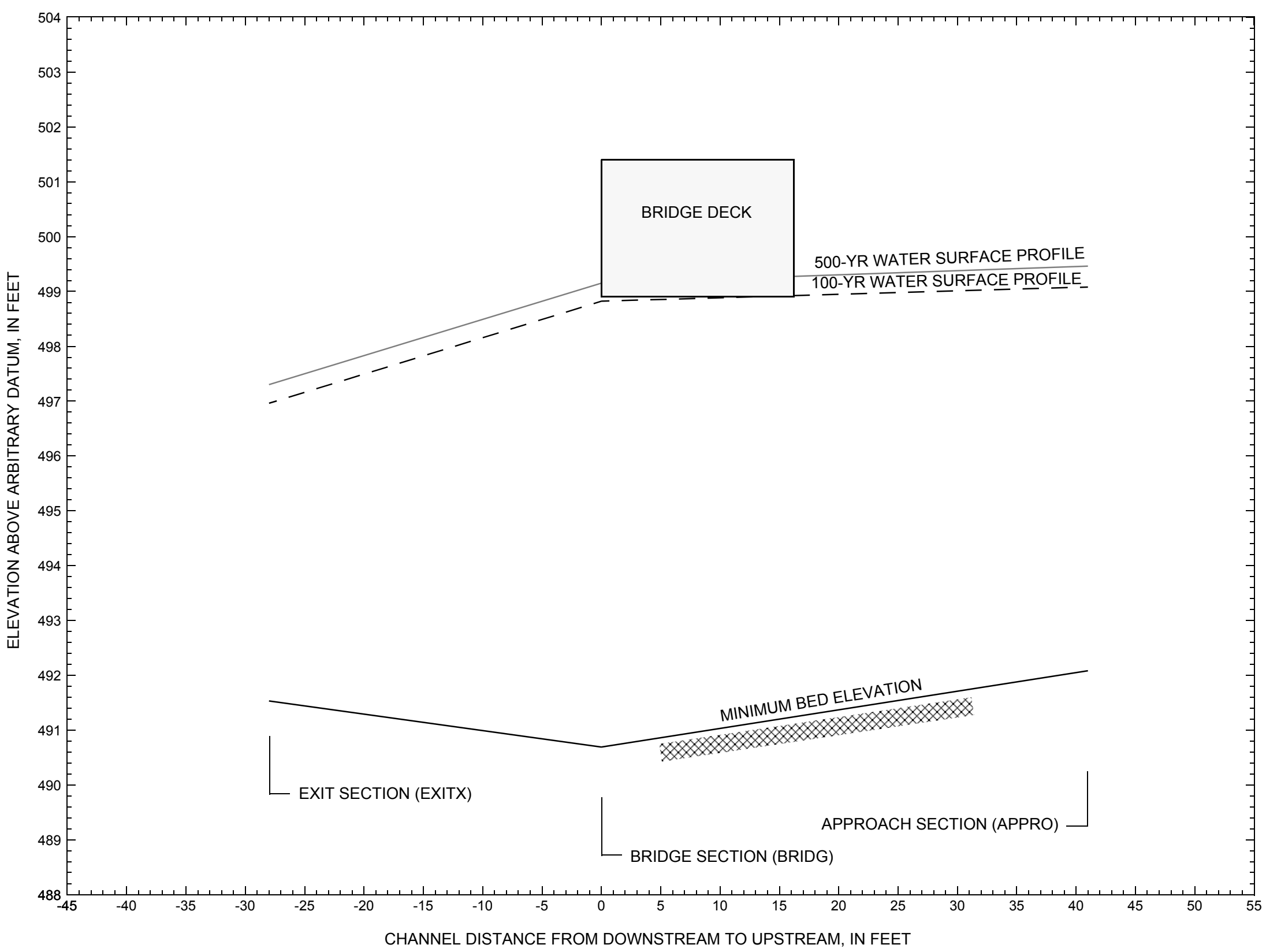

Figure 7. Water-surface profiles for the 100- and 500-yr discharges at structure ATHETH00090008 on Town Highway 9, crossing Bull Creek, Athens, Vermont. 


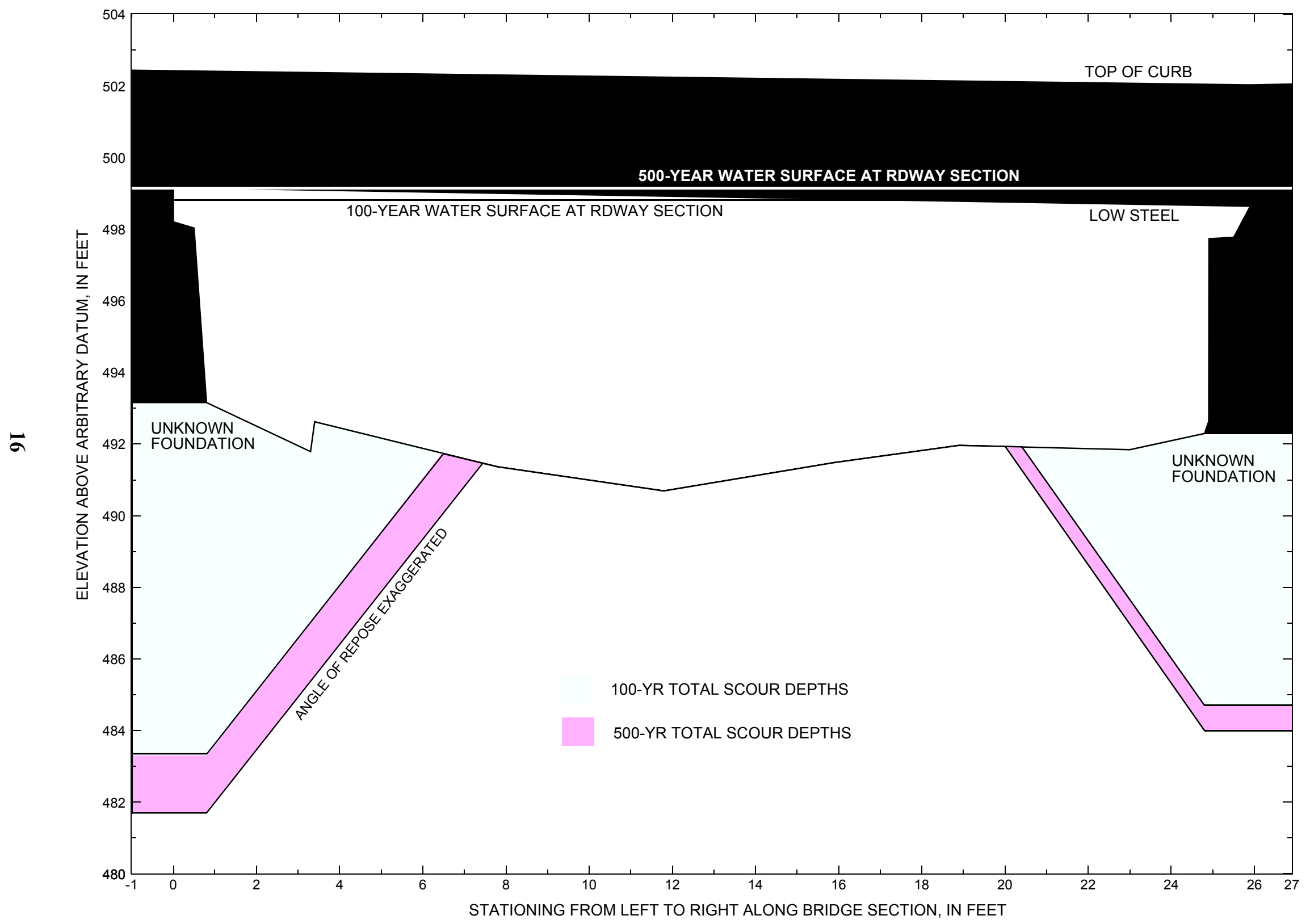

Figure 8. Scour elevations for the 100-yr and 500-yr discharges at structure ATHETH00090008 on Town Highway 9, crossing Bull Creek, Athens, Vermont. 


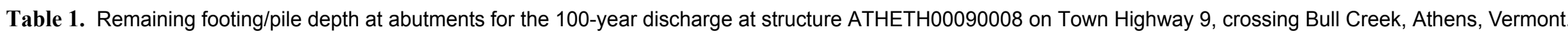
[VTAOT, Vermont Agency of Transportation; --,no data]

\begin{tabular}{|c|c|c|c|c|c|c|c|c|c|c|c|}
\hline Description & Station $^{1}$ & $\begin{array}{l}\text { VTAOT } \\
\text { minimum } \\
\text { low-chord } \\
\text { elevation } \\
\text { (feet) }\end{array}$ & $\begin{array}{l}\text { Surveyed } \\
\text { minimum } \\
\text { low-chord } \\
\text { elevation } \\
\text { (feet) }\end{array}$ & $\begin{array}{c}\text { Bottom of } \\
\text { footing } \\
\text { elevation } \\
\text { (feet) }\end{array}$ & $\begin{array}{c}\text { Channel } \\
\text { elevation at } \\
\text { abutment/ } \\
\text { pier }^{2} \\
\text { (feet) }\end{array}$ & $\begin{array}{l}\text { Contraction } \\
\text { scour depth } \\
\text { (feet) }\end{array}$ & $\begin{array}{l}\text { Abutment } \\
\text { scour } \\
\text { depth } \\
\text { (feet) }\end{array}$ & $\begin{array}{l}\text { Pier } \\
\text { scour } \\
\text { depth } \\
\text { (feet) }\end{array}$ & $\begin{array}{l}\text { Depth of } \\
\text { total scour } \\
\text { (feet) }\end{array}$ & $\begin{array}{c}\text { Elevation of } \\
\text { scour }^{2} \\
\text { (feet) }\end{array}$ & $\begin{array}{c}\text { Remaining } \\
\text { footing/pile } \\
\text { depth } \\
\text { (feet) }\end{array}$ \\
\hline \multicolumn{12}{|c|}{100 -yr. discharge is 2,160 cubic-feet per second } \\
\hline Left abutment & 0.0 & -- & 499.2 & -- & 493.2 & 0.0 & 9.9 & -- & 9.9 & 483.3 & -- \\
\hline Right abutment & 25.9 & -- & 498.6 & -- & 492.3 & 0.0 & 7.6 & -- & 7.6 & 484.7 & -- \\
\hline
\end{tabular}

1.Measured along the face of the most constricting side of the bridge.

2.Arbitrary datum for this study.

Table 2. Remaining footing/pile depth at abutments for the 500-year discharge at structure ATHETH00090008 on Town Highway 9, crossing Bull Creek, Athens, Vermont. [VTAOT, Vermont Agency of Transportation; --, no data]

\begin{tabular}{|c|c|c|c|c|c|c|c|c|c|c|c|}
\hline Description & Station $^{1}$ & $\begin{array}{l}\text { VTAOT } \\
\text { minimum } \\
\text { low-chord } \\
\text { elevation } \\
\text { (feet) }\end{array}$ & $\begin{array}{l}\text { Surveyed } \\
\text { minimum } \\
\text { low-chord } \\
\text { elevation } \\
\text { (feet) }\end{array}$ & $\begin{array}{c}\text { Bottom of } \\
\text { footing } \\
\text { elevation } \\
\text { (feet) }\end{array}$ & $\begin{array}{c}\text { Channel } \\
\text { elevation at } \\
\text { abutment/ } \\
\text { pier }^{2} \\
\text { (feet) }\end{array}$ & $\begin{array}{l}\text { Contraction } \\
\text { scour depth } \\
\text { (feet) }\end{array}$ & $\begin{array}{l}\text { Abutment } \\
\text { scour } \\
\text { depth } \\
\text { (feet) }\end{array}$ & $\begin{array}{l}\text { Pier } \\
\text { scour } \\
\text { depth } \\
\text { (feet) }\end{array}$ & $\begin{array}{l}\text { Depth of } \\
\text { total scour } \\
\text { (feet) }\end{array}$ & $\begin{array}{c}\text { Elevation of } \\
\text { scour }^{2} \\
\text { (feet) }\end{array}$ & $\begin{array}{c}\text { Remaining } \\
\text { footing/pile } \\
\text { depth } \\
\text { (feet) }\end{array}$ \\
\hline \multicolumn{12}{|c|}{500 -yr. discharge is 3,000 cubic-feet per second } \\
\hline Left abutment & 0.0 & -- & 499.2 & -- & 493.2 & 0.0 & 11.4 & -- & 11.4 & 481.8 & -- \\
\hline Right abutment & 25.9 & -- & 498.6 & -- & 492.3 & 0.0 & 8.3 & -- & 8.3 & 484.0 & -- \\
\hline
\end{tabular}

1.Measured along the face of the most constricting side of the bridge.

2.Arbitrary datum for this study. 


\section{SELECTED REFERENCES}

Arcement, G.J., Jr., and Schneider, V.R., 1989, Guide for selecting Manning's roughness coefficients for natural channels and flood plains:

U.S. Geological Survey Water-Supply Paper 2339, 38 p.

Barnes, H.H., Jr., 1967, Roughness characteristics of natural channels: U.S. Geological Survey Water-Supply Paper 1849,213 p.

Benson, M. A., 1962, Factors Influencing the Occurrence of Floods in a Humid Region of Diverse Terrain: U.S. Geological Survey WaterSupply Paper 1580-B, 64 p.

Brown, S.A. and Clyde, E.S., 1989, Design of riprap revetment: Federal Highway Administration Hydraulic Engineering Circular No. 11, Publication FHWA-IP-89-016, 156 p.

Federal Highway Administration, 1983, Runoff estimates for small watersheds and development of sound design: Federal Highway Administration Report FHWA-RD-77-158.

Federal Highway Administration, 1993, Stream Stability and Scour at Highway Bridges: Participant Workbook: Federal Highway Administration Report FHWA-HI-91-011.

Froehlich, D.C., 1989, Local scour at bridge abutments in Ports, M.A., ed., Hydraulic Engineering--Proceedings of the 1989 National Conference on Hydraulic Engineering: New York, American Society of Civil Engineers, p. 13-18.

Hayes, D.C.,1993, Site selection and collection of bridge-scour data in Delaware, Maryland, and Virginia: U.S. Geological Survey WaterResources Investigation Report 93-4017, 23 p.

Johnson, C.G. and Tasker, G.D.,1974, Progress report on flood magnitude and frequency of Vermont streams: U.S. Geological Survey OpenFile Report 74-130, 37 p.

Lagasse, P.F., Schall, J.D., Johnson, F., Richardson, E.V., Chang, F., 1995, Stream Stability at Highway Structures: Federal Highway Administration Hydraulic Engineering Circular No. 20, Publication FHWA-IP-90-014, 144 p.

Laursen, E.M., 1960, Scour at bridge crossings: Journal of the Hydraulics Division, American Society of Civil Engineers, v. 86, no. HY2, p. 39-53.

Potter, W. D., 1957a, Peak rates of runoff in the Adirondack, White Mountains, and Maine woods area, Bureau of Public Roads

Potter, W. D., 1957b, Peak rates of runoff in the New England Hill and Lowland area, Bureau of Public Roads

Richardson, E.V. and Davis, S.R., 1995, Evaluating scour at bridges: Federal Highway Administration Hydraulic Engineering Circular No. 18, Publication FHWA-IP-90-017, 204 p.

Richardson, E.V., Simons, D.B., and Julien, P.Y., 1990, Highways in the river environment: Federal Highway Administration Publication FHWA-HI-90-016.

Ritter, D.F., 1984, Process Geomorphology: W.C. Brown Co., Debuque, Iowa, 603 p.

Shearman, J.O., 1990, User's manual for WSPRO--a computer model for water surface profile computations: Federal Highway Administration Publication FHWA-IP-89-027, 187 p.

Shearman, J.O., Kirby, W.H., Schneider, V.R., and Flippo, H.N., 1986, Bridge waterways analysis model; research report: Federal Highway Administration Publication FHWA-RD-86-108, 112 p.

Talbot, A.N., 1887, The determination of water-way for bridges and culverts.

U.S. Department of Transportation, 1993, Stream stability and scour at highway bridges, Participant Workbook: Federal Highway Administration Publication FHWA HI-91-011.

U.S. Geological Survey, 1984, Saxtons River, Vermont 7.5 by 15 Minute Series quadrangle map: U.S. Geological Survey Topographic Maps, Aerial photographs, 1977; Contour interval, 6 meters; Scale 1:25,000.

U.S. Geological Survey, 1984, Townshend, Vermont 7.5 by 15 Minute Series quadrangle map: U.S. Geological Survey Topographic Maps, Aerial photographs, 1977; Contour interval, 6 meters; Scale 1:25,000. 


\section{APPENDIX A: \\ WSPRO INPUT FILE}




\section{WSPRO INPUT FILE}

GR

GR

GR

GR

GR

GR

$N$

SA

GR

GR

GR

GR

GR

GR

GR

*

\section{$\mathrm{N}$}

SA

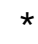

*

BR

GR

GR

GR

GR

GR

*

CD

$\mathrm{N}$

*

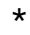

$\mathrm{XR}$

GR

GR

GR

GR

GR

*

$\mathrm{XT}$

GR

GR
U.S. Geological Survey WSPRO Input File athe008.wsp Hydraulic analysis for structure ATHETH00090008 Date: 12-MAR-97 Town Highway 9 Bridge Crossing Bull Creek, Athens, VT

EMB

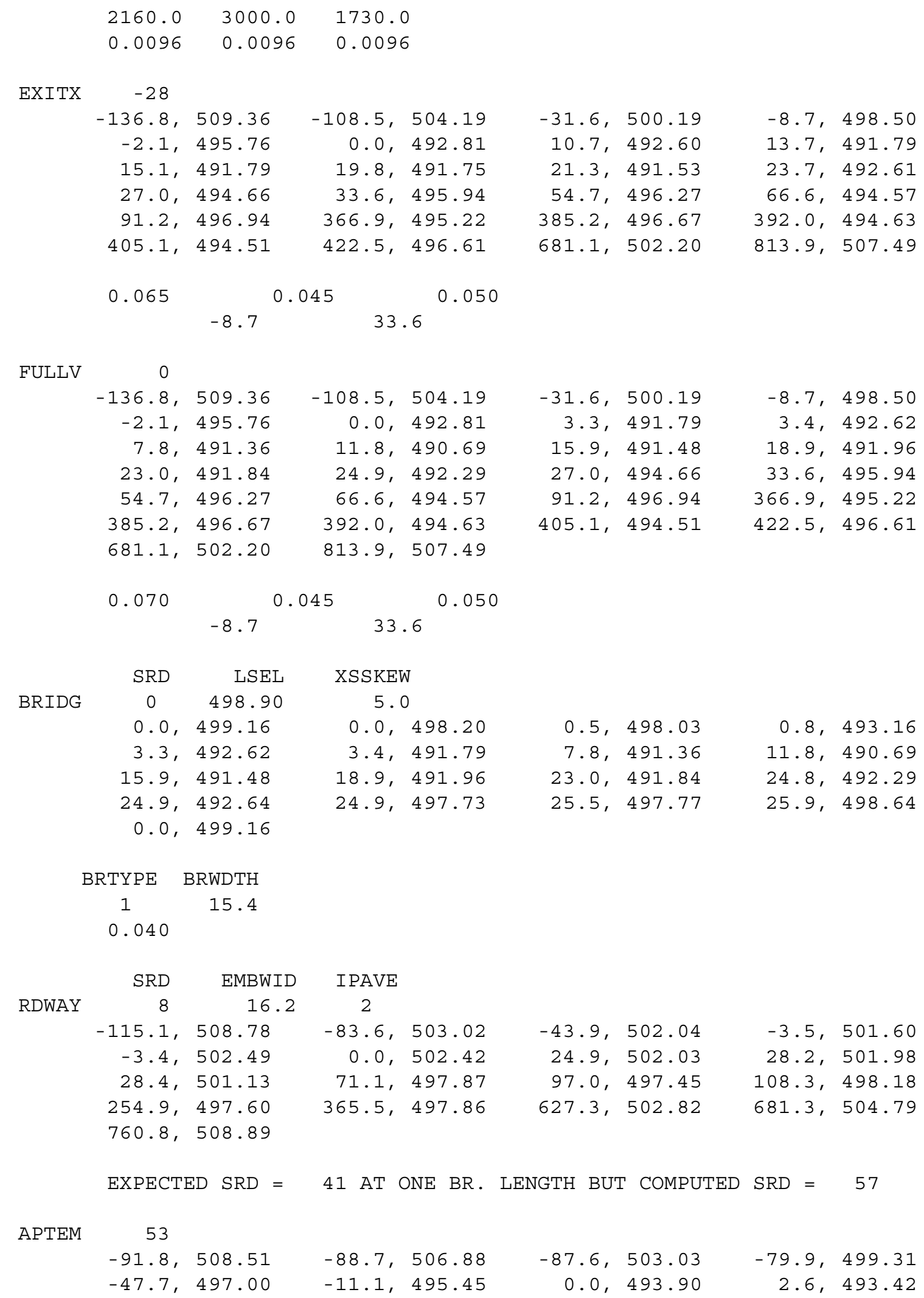




\section{WSPRO INPUT FILE (continued)}

\begin{tabular}{|c|c|c|c|c|}
\hline GR & $11.0,493.49$ & $16.0,494.06$ & $21.1,493.20$ & $23.3,492.47$ \\
\hline GR & 493.33 & $29.0,497.45$ & $54.7,496.27$ & $91.2,496.94$ \\
\hline GR & 495.22 & $385.2,496.67$ & $422.5,496.61$ & $681.1,502.20$ \\
\hline GR & $813.9,507.49$ & & & \\
\hline
\end{tabular}

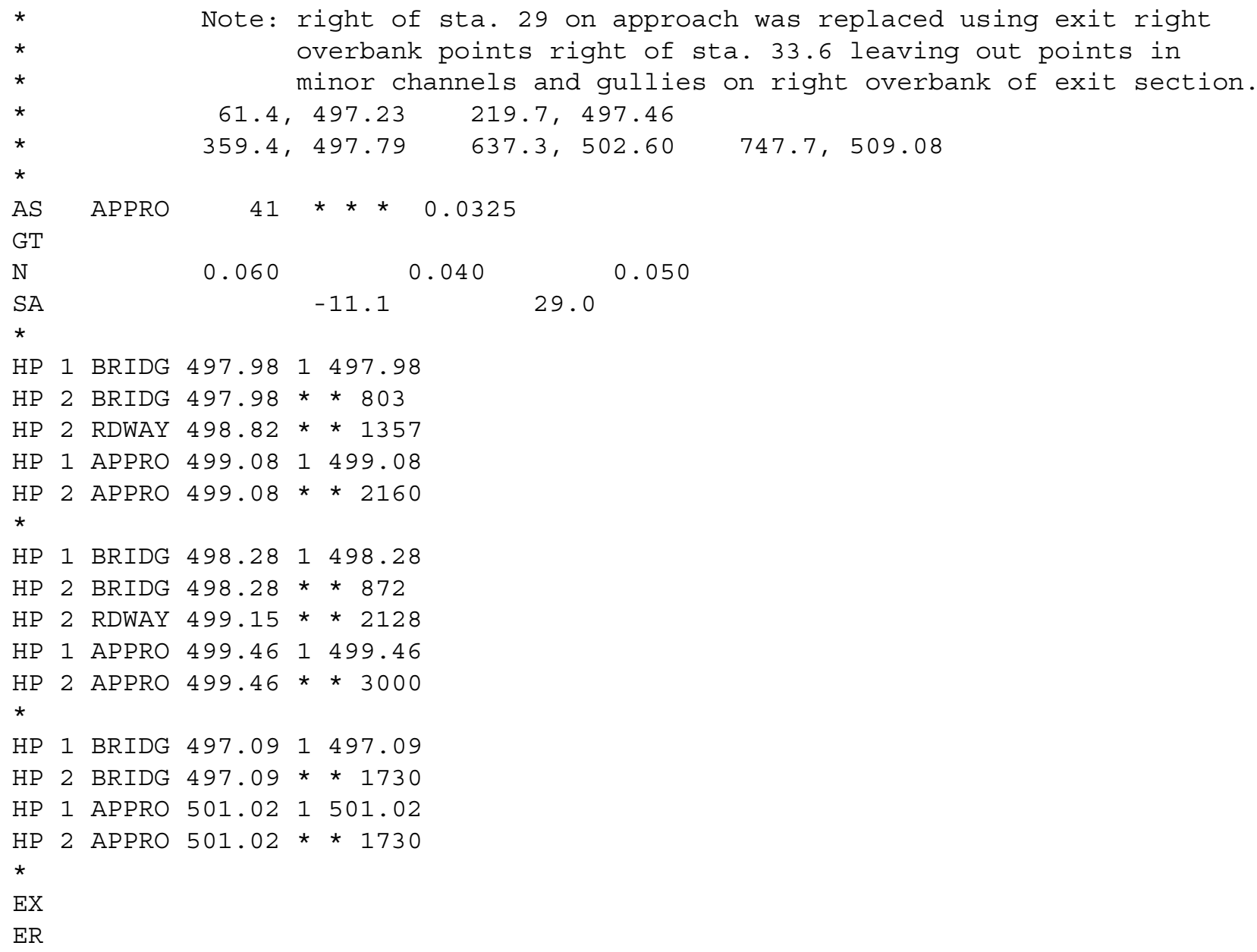




\section{APPENDIX B: \\ WSPRO OUTPUT FILE}


WSPRO OUTPUT FILE

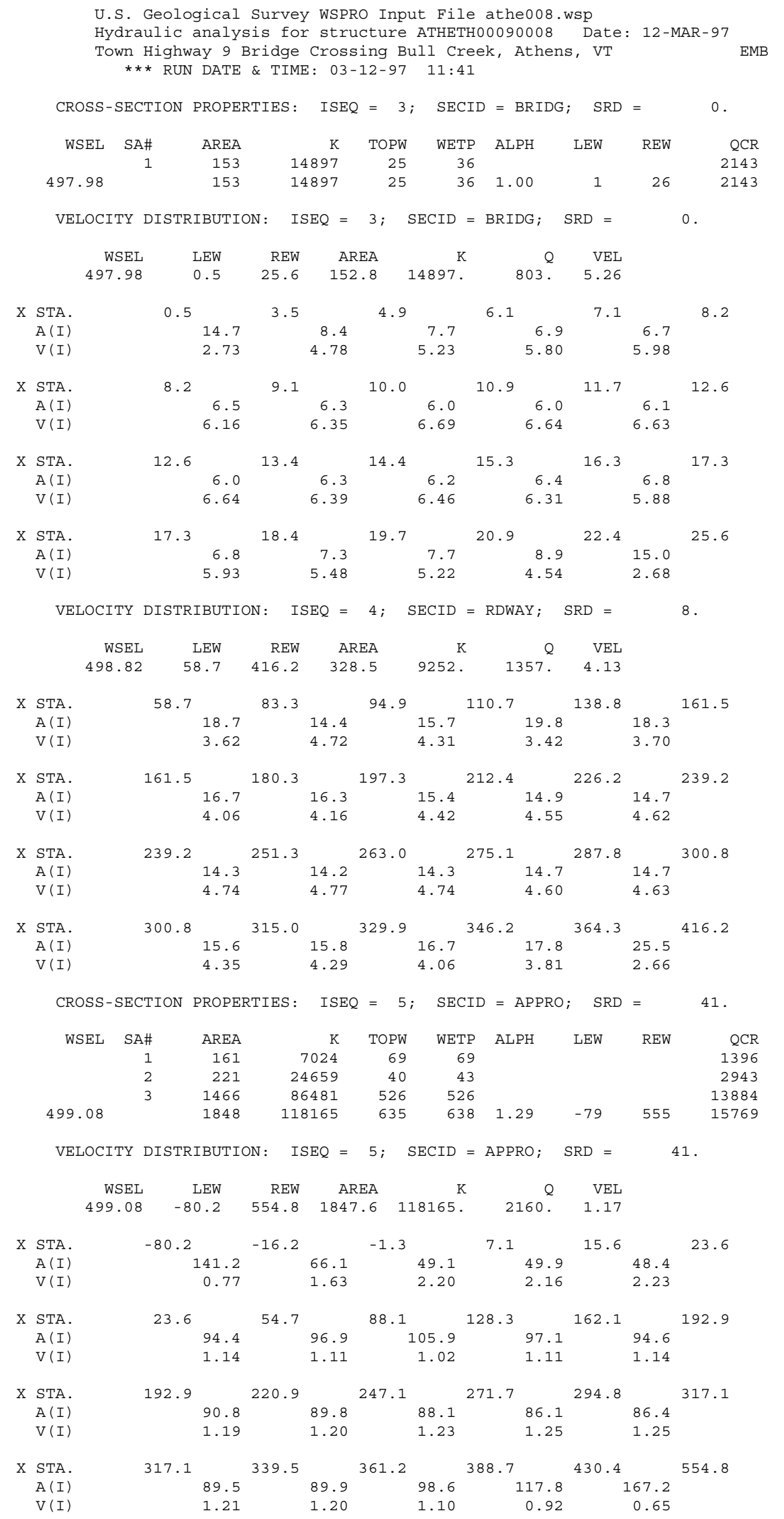


WSPRO OUTPUT FILE (continued)

\author{
U.S. Geological Survey WSPRO Input File athe008.wsp \\ Hydraulic analysis for structure ATHETH00090008 Date: 12-MAR-97 \\ Town Highway 9 Bridge Crossing Bull Creek, Athens, VT EMB \\ *** RUN DATE \& TIME: 03-12-97 11:41 \\ CROSS-SECTION PROPERTIES: $\quad$ ISEQ $=3 ;$ SECID $=$ BRIDG $; \quad$ SRD $=0$.

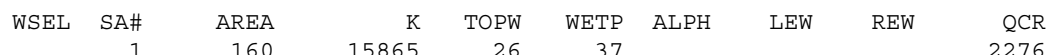 \\ $\begin{array}{lllllllll}498.28 & 1 & 160 & 15865 & 26 & 37 & & & \\ & 160 & 15865 & 26 & 37 & 1.00 & 0 & 26 & 2276\end{array}$ \\ VELOCITY DISTRIBUTION: ISEQ $=3 ;$ SECID $=$ BRIDG; $\operatorname{SRD}=\quad 0$.

\begin{tabular}{|c|c|c|c|c|c|c|c|c|c|c|}
\hline & & WSEL & LEW & REW & & EA & K & $Q$ & VEL & \\
\hline & & 498.28 & 0.0 & 25.7 & 160 & & 15865. & 872. & 5.44 & \\
\hline $\mathrm{x}$ & STA. & & 0.0 & 3.5 & & 4.9 & & 6.1 & 7.2 & 8.2 \\
\hline & $A(I)$ & & 15.6 & & 9.4 & & 7.8 & 7.5 & 7.0 & \\
\hline & $V(I)$ & & 2.79 & & 4.66 & & 5.56 & 5.85 & 6.20 & \\
\hline $\mathrm{x}$ & STA. & & 8.2 & 9.2 & & 10.1 & & 11.0 & 11.8 & 12.7 \\
\hline & $A(I)$ & & 6.8 & & 6.4 & & 6.5 & 6.3 & 6.3 & \\
\hline & $V(I)$ & & 6.40 & & 6.80 & & 6.73 & 6.92 & 6.93 & \\
\hline $\mathrm{X}$ & STA. & & 12.7 & 13.5 & & 14.4 & & 15.3 & 16.4 & 17.4 \\
\hline & $A(I)$ & & 6.3 & & 6.5 & & 6.4 & 6.9 & 6.9 & \\
\hline & $V(I)$ & & 6.96 & & 6.70 & & 6.76 & 6.34 & 6.35 & \\
\hline $\mathrm{X}$ & STA. & & 17.4 & 18.5 & & 19.7 & & 21.0 & 22.5 & 25.7 \\
\hline & $A(I)$ & & 7.1 & & 7.7 & & 8.3 & 9.3 & 15.5 & \\
\hline & $V(I)$ & & 6.18 & & 5.70 & & 5.27 & 4.69 & 2.81 & \\
\hline
\end{tabular} \\ VELOCITY DISTRIBUTION: ISEQ $=4 ; \operatorname{SECID}=$ RDWAY $; \quad \operatorname{SRD}=\quad 8$.

\begin{tabular}{|c|c|c|c|c|c|c|c|c|c|c|c|}
\hline & & ISEL & LEW & REW & ARI & EA & $\mathrm{K}$ & $Q$ & VEL & & \\
\hline & 499 & .15 & 54.3 & 433.6 & 450 & .1 & 15032 . & 2128. & 4.73 & & \\
\hline $\mathrm{X}$ & STA. & 54.3 & & 82.5 & & 95.1 & 111 & 1.7 & 136.1 & & 156.6 \\
\hline & $A(I)$ & & 26.3 & & 19.8 & & 21.6 & 25.2 & & 22.9 & \\
\hline & $\mathrm{V}(\mathrm{I})$ & & 4.04 & & 5.37 & & 4.93 & 4.22 & & 4.65 & \\
\hline $\mathrm{X}$ & STA. & 156.6 & & 175.4 & & 192.6 & 208 & 8.1 & 222.9 & & 236.7 \\
\hline & $A(I)$ & & 22.5 & & 21.9 & & 20.7 & 20.6 & & 20.1 & \\
\hline & $V(I)$ & & 4.73 & & 4.86 & & 5.14 & 5.17 & & 5.29 & \\
\hline $\mathrm{X}$ & STA. & 236.7 & & 249.9 & & 262.6 & 275 & 5.7 & 289.5 & & 303.6 \\
\hline & $A(I)$ & & 19.8 & & 19.6 & & 19.9 & 20.5 & & 20.5 & \\
\hline & $V(I)$ & & 5.38 & & 5.42 & & 5.36 & 5.19 & & 5.19 & \\
\hline $\mathrm{X}$ & STA. & 303.6 & & 318.7 & & 334.3 & 351 & 1.3 & 371.3 & & 433.6 \\
\hline & $A(I)$ & & 21.3 & & 21.6 & & 22.8 & 25.7 & & 36.7 & \\
\hline & $V(I)$ & & 4.99 & & 4.93 & & 4.66 & 4.14 & & 2.90 & \\
\hline & CROSS & SECTION & PROPER' & TIES : & ISEQ & $=5 ;$ & SECID & $=\mathrm{APPRO} ;$ & SRD & $=$ & 41. \\
\hline & WSEL & SA\# & AREA & & K & TOPW & WETP & ALPH & LEW & REW & QCR \\
\hline & & 1 & 188 & & 3972 & 70 & 70 & & & & 1743 \\
\hline & & 2 & 236 & & 558 & 40 & 43 & & & & 3253 \\
\hline & & 3 & 1669 & 105 & 5042 & 543 & 544 & & & & 16593 \\
\hline & 499.46 & & 2092 & 141 & 572 & 653 & 656 & 1.25 & -80 & 572 & 18983 \\
\hline
\end{tabular} \\ VELOCITY DISTRIBUTION : ISEQ $=5 ;$ SECID $=$ APPRO $; \quad$ SRD $=41$.

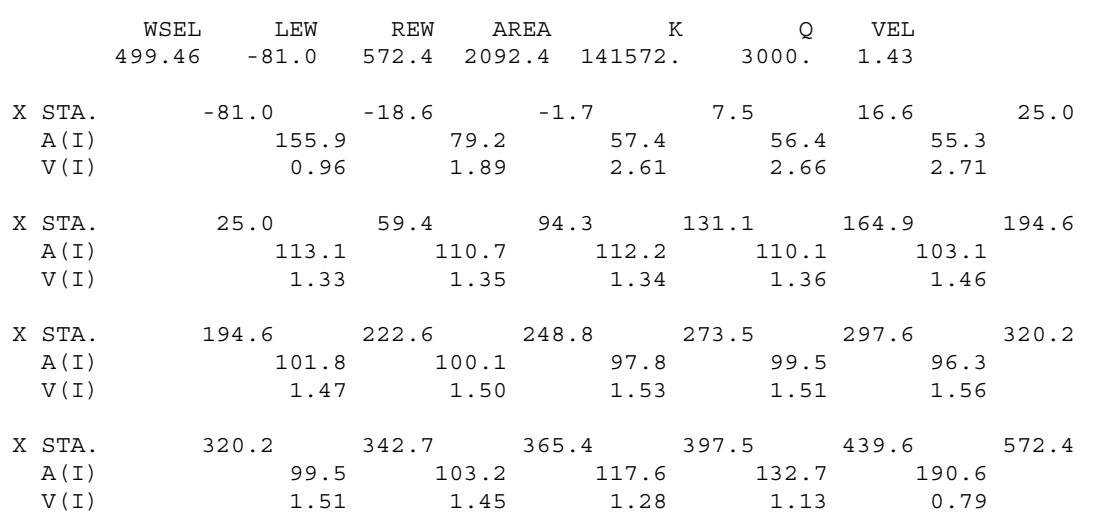


WSPRO OUTPUT FILE (continued)

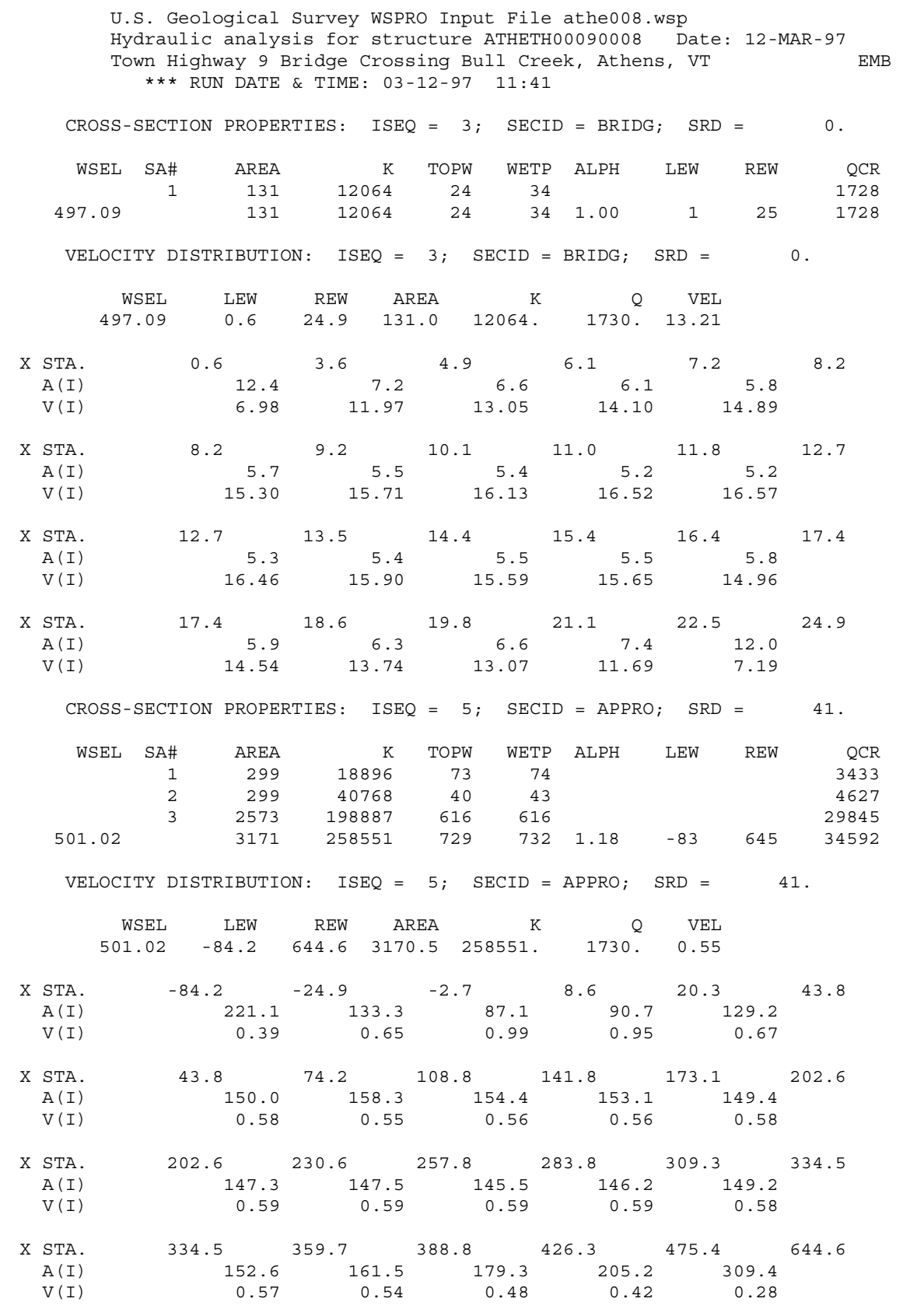


WSPRO OUTPUT FILE (continued)

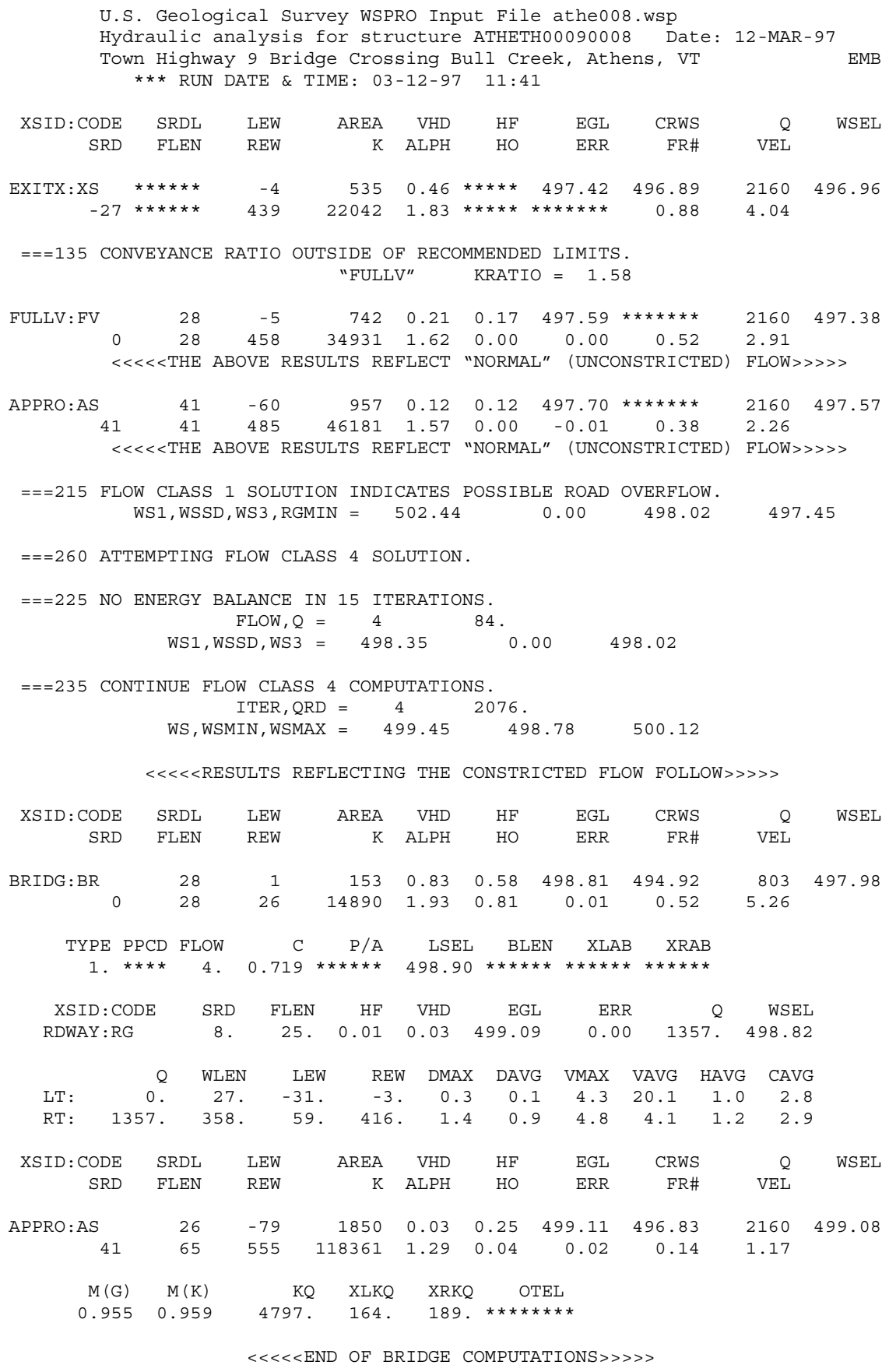

FIRST USER DEFINED TABLE.

\begin{tabular}{|c|c|c|c|c|c|c|c|c|}
\hline XSID : CODE & SRD & LEW & REW & $\mathrm{Q}$ & $\mathrm{K}$ & AREA & VEL & WSEL \\
\hline EXITX:XS & -28 & -5 & 439. & 2160 . & 22042 . & 535. & 4.04 & 496.96 \\
\hline FULLV : FV & 0 . & -6 . & 458. & 2160 . & 34931 . & 742 . & 2.91 & 497.38 \\
\hline BRIDG : BR & 0 . & 1. & 26 & 803 & 14890. & 153. & 5.26 & 497.98 \\
\hline RDWAY : RG & $8 \cdot *$ & 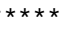 & 0 & 1357. & \multicolumn{2}{|c|}{$0 . * * \star \star * \star * * * *$} & 2.00 & 498.82 \\
\hline APPRO : AS & 41. & -80 & 555. & 2160 . & 118361 . & 1850. & 1.17 & 499.08 \\
\hline XSID : CODE & XLKQ & XRKQ & & & & & & \\
\hline APPRO : AS & 164. & 189. & 4797 & & & & & \\
\hline
\end{tabular}

SECOND USER DEFINED TABLE.

\begin{tabular}{|c|c|c|c|c|c|c|c|c|c|}
\hline XSID : CODE & CRWS & FR\# & YMIN & YMAX & $\mathrm{HF}$ & $\mathrm{HO}$ & VHD & EGL & WSEI \\
\hline EXITX:XS & 496.89 & 0.88 & 491.53 & $509.36 *$ & 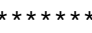 & 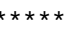 & 0.46 & 497.42 & 496. \\
\hline FULLV : FV & 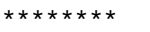 & 0.52 & 490.69 & 509.36 & 0.17 & 0.00 & 0.21 & 497.59 & 497 \\
\hline BRIDG : BR & 494.92 & 0.52 & 490.69 & 499.16 & 0.58 & 0.81 & 0.83 & 498.81 & 497. \\
\hline RDWAY : RG & $\star \star \star \star \star * \star * \star * \star * \star *$ & $\star * \star * *$ & 497.45 & 508.89 & $0.01 * *$ & $\star \star * \star * *$ & 0.03 & 499.09 & 498.8 \\
\hline APPRO:AS & 496.83 & 0.14 & 492.08 & 508.12 & 0.25 & 0.04 & 0.03 & 499.11 & 499.0 \\
\hline
\end{tabular}


WSPRO OUTPUT FILE (continued)

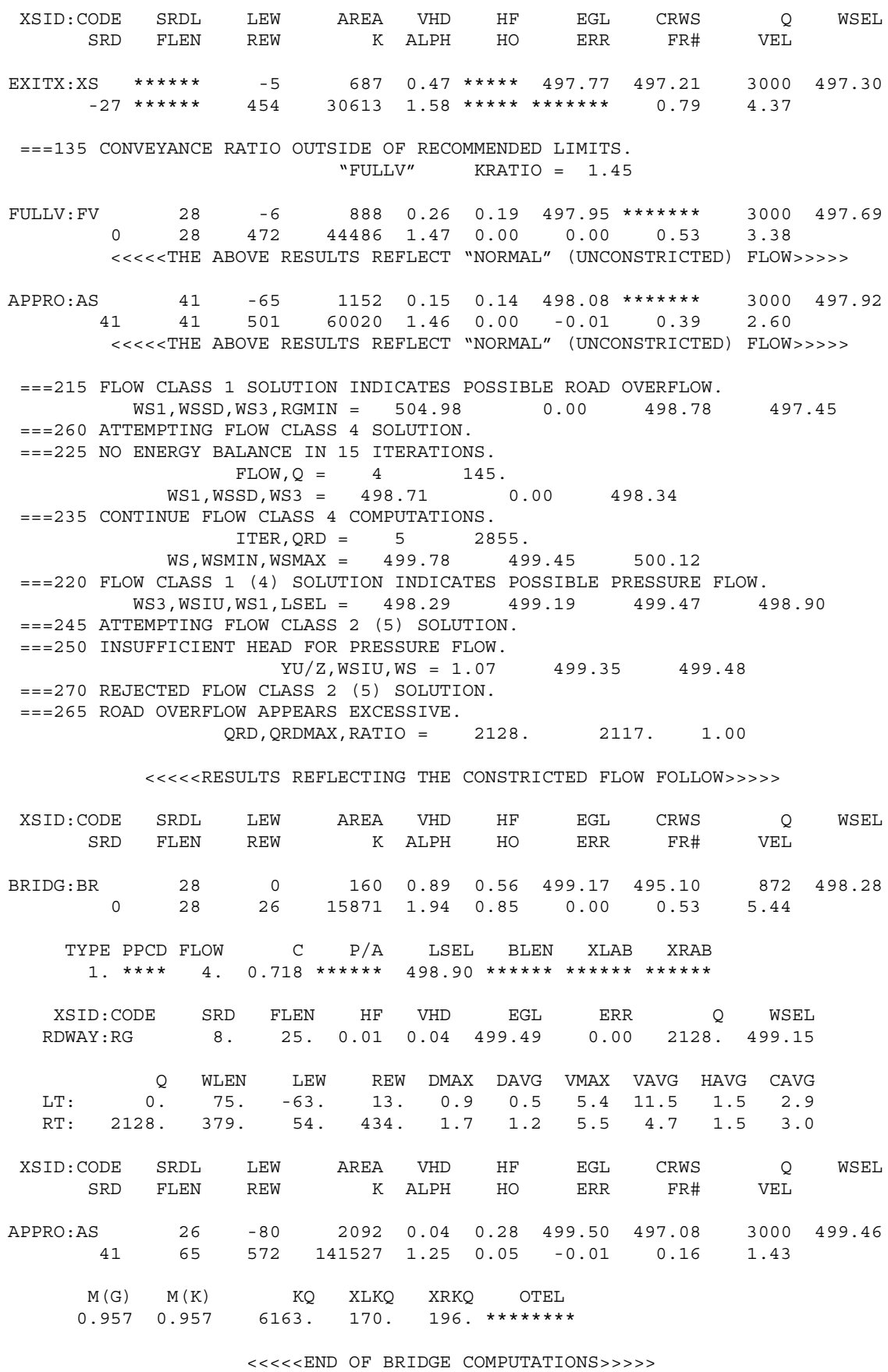


WSPRO OUTPUT FILE (continued)

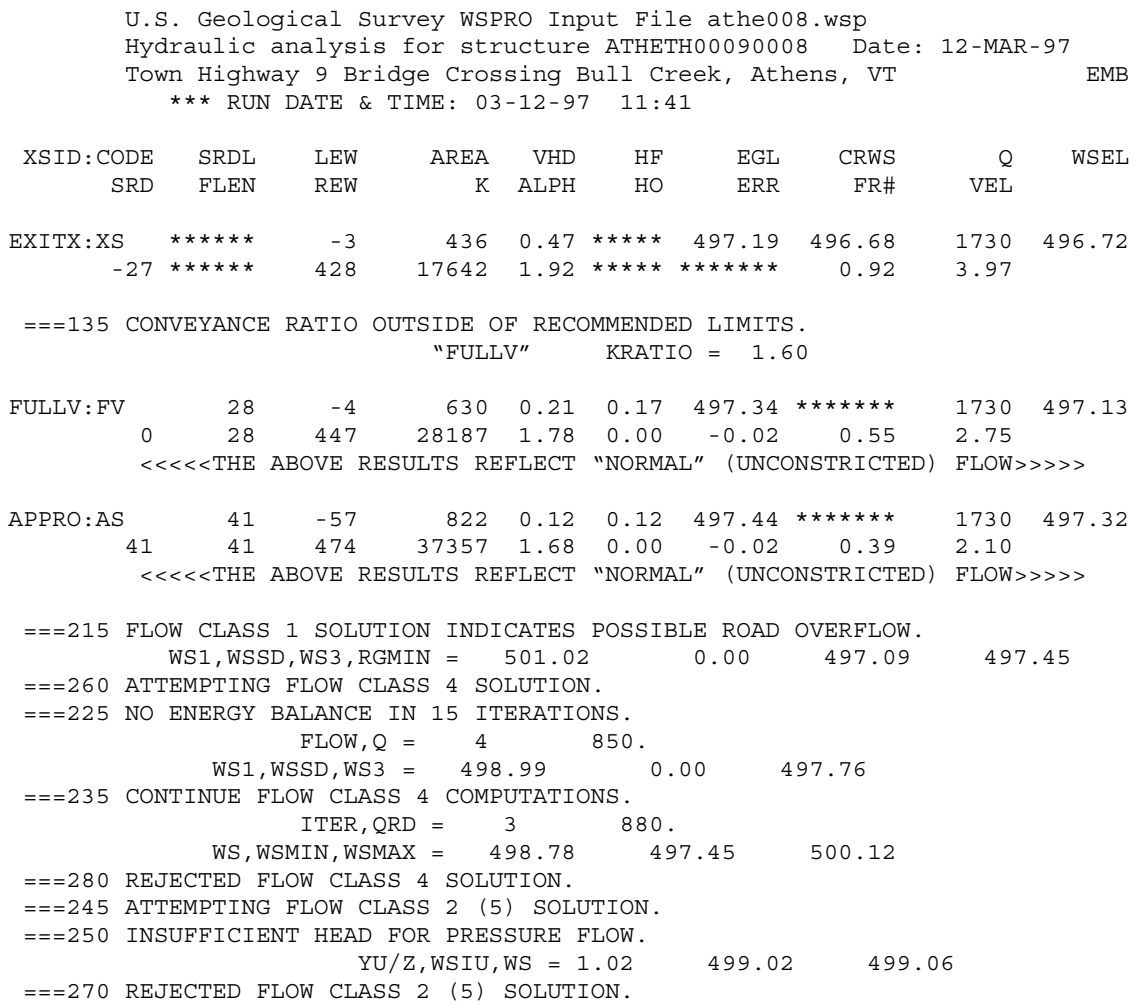

FIRST USER DEFINED TABLE.

\begin{tabular}{|c|c|c|c|c|c|c|c|c|}
\hline XSID : CODE & SRD & LEW & REW & $Q$ & $\mathrm{~K}$ & AREA & VEL & WSEL \\
\hline EXITX:XS & -28 & -4 & 428 & 1730. & 17642 . & 436. & 3.97 & 496.72 \\
\hline FULLV : FV & 0 & -5 & 447. & 1730. & 28187. & 630. & 2.75 & 497.13 \\
\hline BRIDG : BR & 0 . & 1. & 25 & 1730. & 12064 . & 131. & 13.21 & 497.09 \\
\hline RDWAY : RG & \multicolumn{3}{|c|}{$8 . * * * * \star * * * * * * * * *$} & 0 & \multicolumn{2}{|c|}{$0 . * * * \star * * * * *$} & \multicolumn{2}{|c|}{$2.00 * * * * * * * *$} \\
\hline APPRO : AS & 41. & -84 & 645. & 1730. & 258655 . & 3171. & 0.55 & 501.02 \\
\hline XSID : CODE & XLKQ & XRKQ & & & & & & \\
\hline APPRO : AS & 156. & 180. & 10433 & & & & & \\
\hline
\end{tabular}

SECOND USER DEFINED TABLE.

$\begin{array}{lcrrrrrrrr}\text { XSID : CODE } & \text { CRWS } & \text { FR\# } & \text { YMIN } & \text { YMAX } & \text { HF } & \text { HO } & \text { VHD } & \text { EGL } & \text { WSEL } \\ \text { EXITX :XS } & 496.68 & 0.92 & 491.53 & 509.36 * * * * * * * * * * * & 0.47 & 497.19 & 496.72 \\ \text { FULLV :FV } & * * * * * * * & 0.55 & 490.69 & 509.36 & 0.17 & 0.00 & 0.21 & 497.34 & 497.13 \\ \text { BRIDG : BR } & 494.83 & 1.15 & 490.69 & 499.16 & 0.46 & 1.84 & 3.55 & 500.64 & 497.09 \\ \text { RDWAY : RG } & * * * * * * * * * * * * * * & 497.45 & 508.89 * * * * * * * * * * & 0.02 & 499.07 * * * * * * * \\ \text { APPRO:AS } & 496.69 & 0.05 & 492.08 & 508.12 & 0.07 & 0.32 & 0.01 & 501.03 & 501.02\end{array}$




\section{APPENDIX C:}

\section{BED-MATERIAL PARTICLE-SIZE DISTRIBUTION}




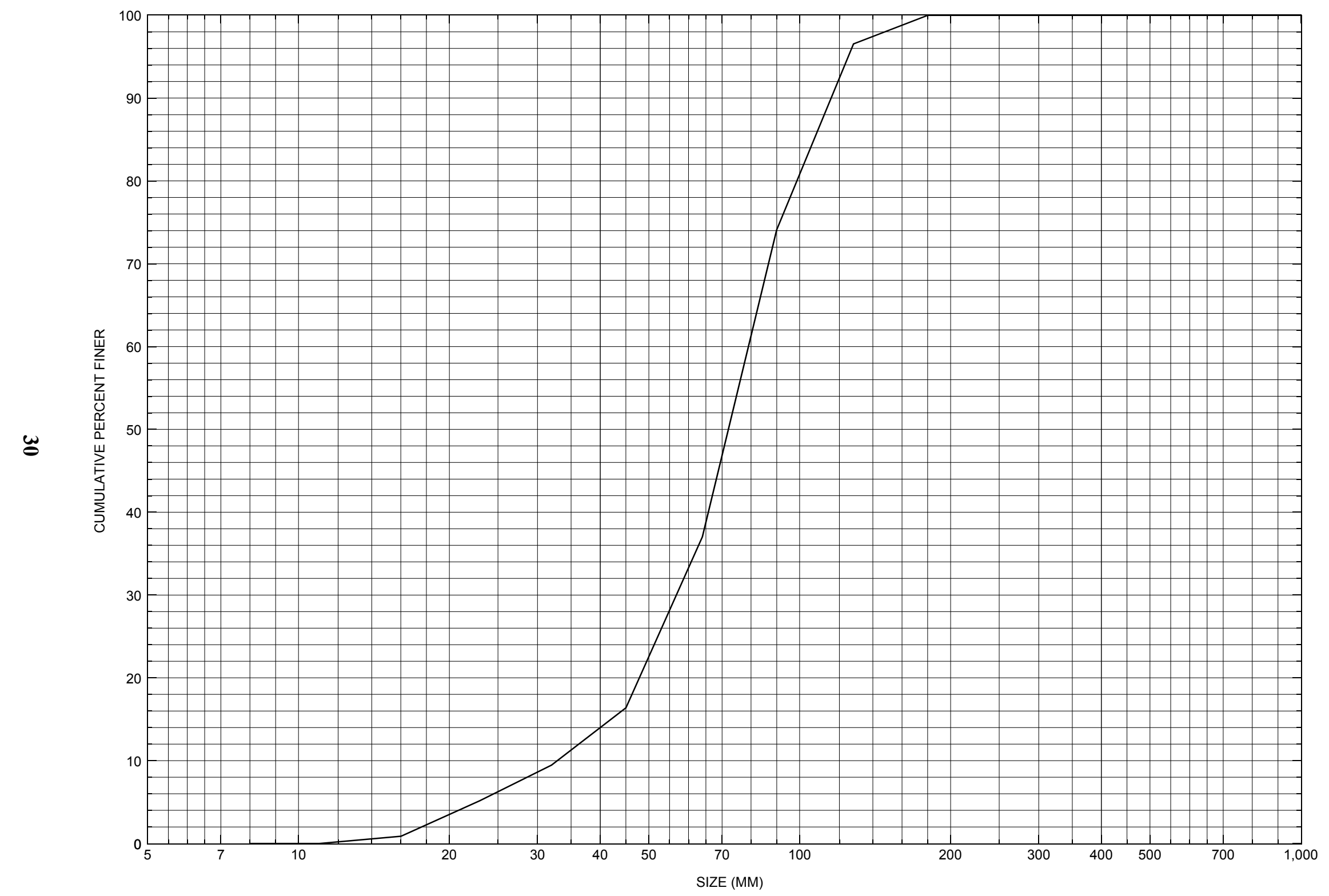

Appendix C. Bed material particle-size distribution for a pebble count in the channel approach of structure ATHETH00090008, in Athens, Vermont. 


\section{APPENDIX D: \\ HISTORICAL DATA FORM}




\section{Structure Number ATHETH00090008}

\section{General Location Descriptive}

Data collected by (First Initial, Full last name) $\underline{\text { M. IVANOFF }}$

Date $(M M / D D / Y Y) \_\mathbf{0 4} / \underline{05} / \underline{95}$

Highway District Number (I - 2; nn) $\mathbf{0 2}$

Town (FIPS place code; I - 4; nnnnn) $\mathbf{0 1 9 0 0}$

Waterway (I - 6) BULL CREEK

Route Number TH009

Topographic Map Saxtons River

Latitude (I - 16; nnnn.n) $\mathbf{4 3 0 7 8}$
County (FIPS county code; I - 3; nnn)

Mile marker (I - 11; nnn.nnn) $\mathbf{0 0 0 0 0 0}$

Road Name (I - 7): -

Vicinity (I - 9) 0.05 MI TO JCT W CL2 TH2

Hydrologic Unit Code: $\mathbf{0 1 0 8 0 1 0 7}$

Longitude (i - 17; nnnnn.n) $\mathbf{7 2 3 4 0}$

\section{Select Federal Inventory Codes}

FHWA Structure Number (I - 8) 10130100081301

Maintenance responsibility $(I-21 ; n n) \quad \mathbf{0 3}$

Year built (I - 27; YYYY) 1991

Average daily traffic, ADT (I - 29; nnnnnn) 000020

Year of ADT (I - 30; YY) $\mathbf{9 0}$

Opening skew to Roadway $(I-34 ; n n) \quad 09$

Operational status $(I-41 ; X) \quad \mathbf{A}$

Structure type (I- 43; nnn) $\mathbf{3 0 2}$

Approach span structure type (I - 44; nnn) $\mathbf{0 0 0}$

Number of spans (I - 45; nnn) $\mathbf{0 0 1}$

Number of approach spans (I - 46; nnnn) $\mathbf{0 0 0 0}$

Comments:

The structural inspection report of $07 / 11 / 95$ indicates the structure is a steel beam type bridge with a timber deck. Both abutments are laid up stone with newer concrete bearing caps and backwalls. The stonework has some random voids which could be filled with chinker stone. There is stone fill upstream from both abutments. There are a few large logs lying along the bank downstream from the right abutment. The waterway makes a sharp turn into the structure and most of the flow is directed into the upstream end of the right abutment. There is some very minor localized scour beneath the structure. It is in the middle of the channel and does not appear to be affecting the substructure. (Continued, page 34) 


\section{Bridge Hydrologic Data}

Is there hydrologic data available? $\underline{\mathbf{N}}$ if No, type ctrl-n $h \quad$ VTAOT Drainage area $\left(m i^{2}\right)$ : -

Terrain character:

Stream character \& type: -

Streambed material:

Discharge Data (cfs):

$$
\begin{aligned}
& Q_{2.33}- \\
& Q_{50}-
\end{aligned}
$$

Record flood date $(M M / D D / Y Y)$ :

Estimated Discharge (cfs): Ice conditions (Heavy, Moderate, Light) : -

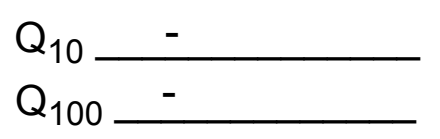

$$
\begin{aligned}
& Q_{25}- \\
& Q_{500}-
\end{aligned}
$$

Water surface elevation $(f t):-$

The stage increases to maximum highwater elevation (Rapidly, Not rapidly):

The stream response is (Flashy, Not flashy):

Describe any significant site conditions upstream or downstream that may influence the stream's stage: -

Watershed storage area (in percent): _ _ \%

The watershed storage area is: - (1-mainly at the headwaters; 2- uniformly distributed; 3-immediatly upstream oi the site)

Water Surface Elevation Estimates for Existing Structure:

\begin{tabular}{|l|l|l|l|l|l|}
\hline Peak discharge frequency & $Q_{2.33}$ & $Q_{10}$ & $Q_{25}$ & $Q_{50}$ & $Q_{100}$ \\
Water surface elevation (ft)) & - & - & - & - & - \\
Velocity (ft/sec) & - & - & - & - & - \\
\hline
\end{tabular}

Long term stream bed changes: -

Is the roadway overtopped below the $\mathrm{Q}_{100}$ ? (Yes, No, Unknown): $\mathbf{U} \quad$ Frequency: Relief Elevation (ft): Discharge over roadway at $Q_{100}\left(f^{3} / \mathrm{sec}\right)$ :

Are there other structures nearby? (Yes, No, Unknown): $\underline{\mathbf{U}}$ Upstream distance (miles): Town: If No or Unknown, type ctrl-n os Highway No. : Structure No. : Year Built:

Clear span (ft): Clear Height $(f t)$ : Full Waterway $\left(f^{2}\right)$ : 
Downstream distance (miles): Town: Year Built:

Highway No. : Structure No. : Structure Type:

Clear span (ft): Clear Height $(f t)$ : Full Waterway $\left(f^{2}\right):$

Comments:

The streambed consists of stone and gravel.

\section{USGS Watershed Data}

Watershed Hydrographic Data

Drainage area $(D A)$ $\mathrm{mi}^{2}$ Lake and pond area

0.10 $\mathrm{mi}^{2}$

Watershed storage (ST) 1.2 $\%$

Bridge site elevation 630 $\mathrm{ft}$

Headwater elevation 1693 $\mathrm{ft}$

Main channel length 4.13 mi $10 \%$ channel length elevation 728 $\mathrm{ft} \quad 85 \%$ channel length elevation $\mathrm{ft}$

Main channel slope $(S)$ 69.89 $\mathrm{ft} / \mathrm{mi}$

Watershed Precipitation Data

Average site precipitation in

Average headwater precipitation in

Maximum 2yr-24hr precipitation event $(124,2)$ in

Average seasonal snowfall (Sn) _$\mathrm{ft}$ 


\section{Bridge Plan Data}

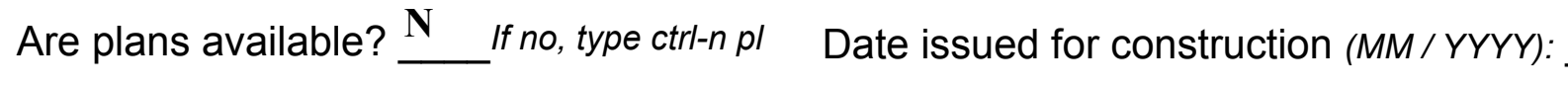

Project Number

Minimum channel bed elevation:

Low superstructure elevation: USLAB DSLAB USRAB DSRAB Benchmark location description:

NO BENCHMARK INFORMATION

Reference Point (MSL, Arbitrary, Other): Datum (NAD27, NAD83, Other):

Foundation Type: 4

If 1: Footing Thickness

If 2: Pile Type: (1-Wood; 2-Steel or metal; 3-Concrete)

If 3 : Footing bottom elevation:

Is boring information available? $\mathbf{N}$ If no, type ctrl-n bi Number of borings taken:

Foundation Material Type: $\mathbf{3}$ (1-regolith, 2-bedrock, 3-unknown)

Briefly describe material at foundation bottom elevation or around piles:

NO FOUNDATION MATERIAL INFORMATION

Comments:

NO PLANS. 


\section{Cross-sectional Data}

Is cross-sectional data available? $\underline{\mathbf{Y}}$

If no, type ctrl-n xs

Source (FEMA, VTAOT, Other)? VTAOT

This cross section is the upstream face. The low chord elevations are from the survey log

Comments: done for this report on 8/15/96. The low chord to bed length data is from the sketch

attached to a bridge inspection report dated 7/11/94.

\begin{tabular}{|c|c|c|c|c|c|c|c|c|c|c|c|}
\hline Station & $\mathbf{0}$ & 0.9 & 3.4 & 9.9 & 13.2 & 16.5 & 23 & 26 & - & - & - \\
\hline Feature & LAB & & & & & & & RAB & - & - & - \\
\hline $\begin{array}{l}\text { Low cord } \\
\text { elevation }\end{array}$ & 499.2 & 499.2 & 499.1 & 499.0 & 498.9 & 498.9 & 498.7 & 498.6 & - & - & - \\
\hline $\begin{array}{l}\text { Bed } \\
\text { elevation }\end{array}$ & - & 491.2 & 490.9 & 489.7 & 489.3 & 489.4 & 489.2 & 489.3 & - & - & - \\
\hline $\begin{array}{l}\text { Low cord to } \\
\text { bed length }\end{array}$ & - & 8.0 & 8.2 & 9.3 & 9.6 & 9.5 & 9.5 & 9.3 & - & - & - \\
\hline Station & - & - & - & - & - & - & - & - & - & - & - \\
\hline Feature & - & - & - & - & - & - & - & - & - & - & - \\
\hline $\begin{array}{l}\text { Low cord } \\
\text { elevation }\end{array}$ & - & - & - & - & - & - & - & - & - & - & - \\
\hline $\begin{array}{l}\text { Bed } \\
\text { elevation }\end{array}$ & - & - & - & - & - & - & - & - & - & - & - \\
\hline $\begin{array}{l}\text { Low cord to } \\
\text { bed length }\end{array}$ & - & - & - & - & - & - & - & - & - & - & - \\
\hline
\end{tabular}

Source (FEMA, VTAOT, Other)?

Comments: --

\begin{tabular}{|l|l|l|l|l|l|l|l|l|l|l|l|}
\hline Station & - & - & - & - & - & - & - & - & - & - & - \\
\hline Feature & - & - & - & - & - & - & - & - & - & - & - \\
\hline $\begin{array}{l}\text { Low cord } \\
\text { elevation }\end{array}$ & - & - & - & - & - & - & - & - & - & - & - \\
\hline $\begin{array}{l}\text { Bed } \\
\text { elevation }\end{array}$ & - & - & - & - & - & - & - & - & - & - & - \\
\hline $\begin{array}{l}\text { Low cord to } \\
\text { bed length }\end{array}$ & - & - & - & - & - & - & - & - & - & - & - \\
\hline \begin{tabular}{l} 
Station \\
\hline Feature
\end{tabular}$-$ & - & - & - & - & - & - & - & - & - & - & - \\
\hline $\begin{array}{l}\text { Low cord } \\
\text { elevation }\end{array}$ & - & - & - & - & - & - & - & - & - & - \\
\hline $\begin{array}{l}\text { Bed } \\
\text { elevation }\end{array}$ & - & - & - & - & - & - & - & - & - & - \\
\hline $\begin{array}{l}\text { Low cord to } \\
\text { bed length }\end{array}$ & - & - & - & - & - & - & - & - & - & - \\
\hline
\end{tabular}




\section{APPENDIX E: \\ LEVEL I DATA FORM}


U. S. Geological Survey

Bridge Field Data Collection and Processing Form

Qa/Qc Check by: EW Date: $\underline{10 / 24 / 96}$

\section{Structure Number}

ATHETH00090008

\section{A. General Location Descriptive}

1. Data collected by (First Initial, Full last name) R. BURNS

2. Highway District Number $\mathbf{0 2}$

Mile marker 000000

County WINDHAM (025)

Town ATHENS (01900)

Waterway (I - 6) Bull Creek

Road Name -

Route Number TH009

Hydrologic Unit Code: $\mathbf{0 1 0 8 0 1 0 7}$

3. Descriptive comments:

Located 0.05 miles from the intersection of Town highway 9 with Town highway 2.

\section{B. Bridge Deck Observations}
4. Surface cover... LBUS 5
RBUS 4
LBDS 5
RBDS 4
Overall 5

(2b us,ds,lb,rb: 1- Urban; 2- Suburban; 3- Row crops; 4- Pasture; 5- Shrub- and brushland; 6- Forest; 7- Wetland)
5. Ambient water surface...US $\underline{2}$
UB 1
DS 1
(1- pool; 2- riffle)

6. Bridge structure type 1 (1- single span; 2- multiple span; 3- single arch; 4- multiple arch; 5- cylindrical culvert; 6- box culvert; or 7- other)
7. Bridge length $\mathbf{3 2}$
(feet)
Span length $\underline{\mathbf{2 8}}$
(feet)
Bridge width 16.2 (feet)

\section{Road approach to bridge:}
8. LB 0
RB 1
( 0 even, 1- lower, 2- higher)
9. LB_2
RB $\underline{2}$
(1-Paved, 2- Not paved)

10. Embankment slope (run / rise in feet / foot)

US left

US right

\begin{tabular}{|c|c|c|c|}
\hline \multicolumn{2}{|c|}{ Protection } & \multirow{2}{*}{ 13.Erosion } & \multirow{2}{*}{ 14.Severity } \\
\hline 11.Type & 12. Cond. & & \\
\hline 1 & 2 & 2 & 1 \\
\hline 2 & 1 & 2 & 1 \\
\hline 2 & 2 & 2 & 1 \\
\hline 2 & 1 & $\mathbf{0}$ & - \\
\hline
\end{tabular}

Bank protection types: 0- none; 1- < 12 inches,

2- < 36 inches; 3- < 48 inches;

4- < 60 inches; 5- wall / artificial levee

Bank protection conditions: 1- good; 2- slumped;

3- eroded; 4- failed

Erosion: 0 - none; 1- channel erosion; 2 -

road wash; 3- both; 4- other

Erosion Severity: 0 - none; 1- slight; 2- moderate; 3- severe

\section{Channel approach to bridge (BF):}

15. Angle of approach: $\mathbf{1 0}$

16. Bridge skew: 15

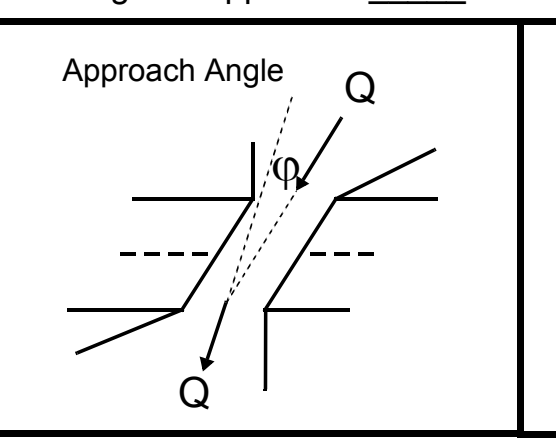

17. Channel impact zone 1:

Where? RB $(L B, R B)$

Range? 30 feet US

Channel impact zone 2:

Where? $(L B, R B)$

Range? feet (US, UB, DS) to feet Bridge Skew Angle

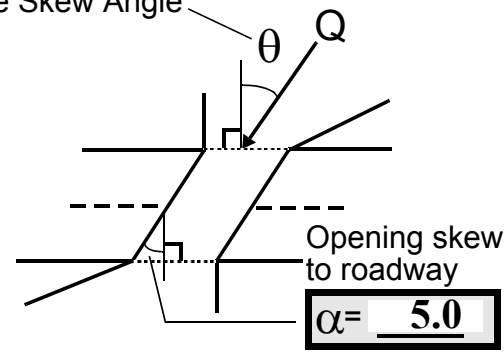

\section{Exist? $\mathbf{Y}(Y$ or $N)$}

Severity 2

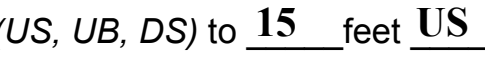

Exist? $\underline{\mathbf{N}}(\mathrm{Y}$ or $N)$

Severity

Impact Severity: 0- none to very slight; 1- Slight; 2- Moderate; 3- Severe 
18. Bridge Type: $\mathbf{1 b}$

1a- Vertical abutments with wingwalls

$1 \mathrm{~b}$ - Vertical abutments without wingwalls

2- Vertical abutments and wingwalls, sloping embankment Wingwalls perpendicular to abut. face

3- Spill through abutments

4- Sloping embankment, vertical wingwalls and abutments

Wingwall angle less than $90^{\circ}$.

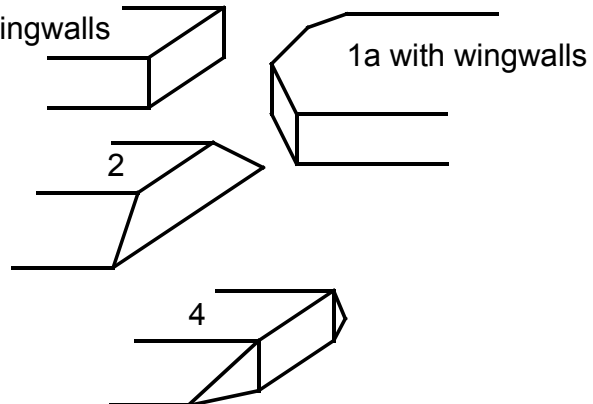

19. Bridge Deck Comments (surface cover variations, measured bridge and span lengths, bridge type variations, approach overflow width, etc.)

There are shrubs and brush on the DSLB, DSRB and USLB. Surface cover on the downstream overbank areas is pasture. The USRB has trees along the bank with lawn on the overbank.

The bridge dimensions measured in the field are the same as the VTAOT database values.

The upstream left road embankment protection is type 2 stone fill. The US right and DS left road embankment protection also is the bank protection.

Road wash has eroded the finer underlying bank material from between the larger stones of the fill protection on the upstream right road embankment.

\section{Upstream Channel Assessment}

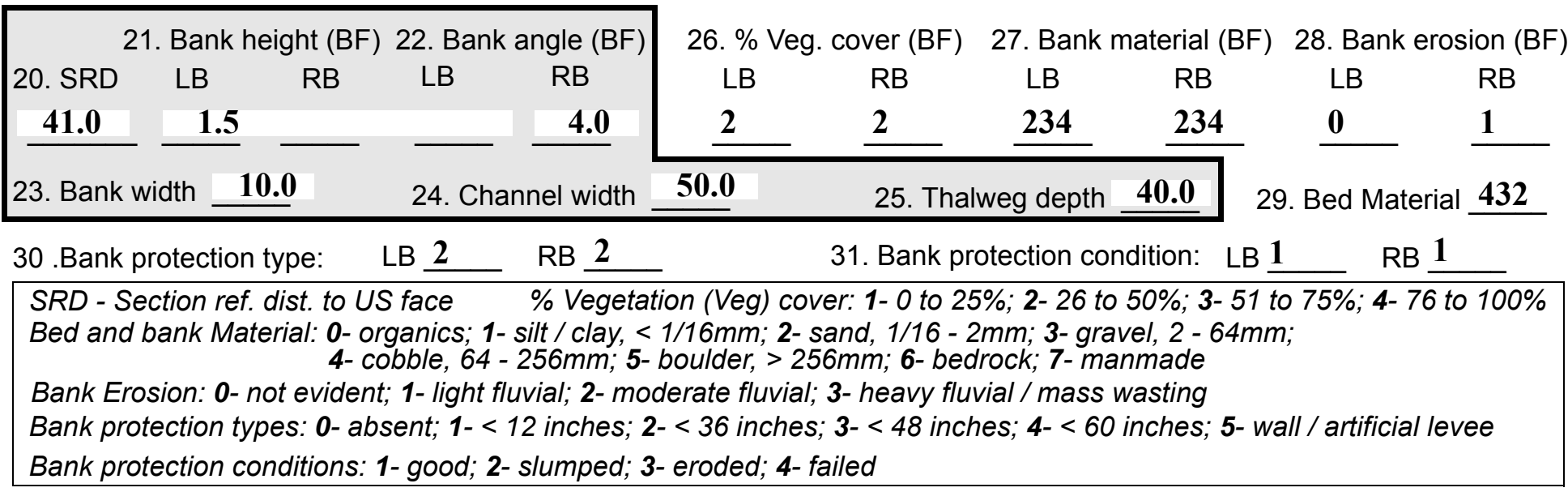

32. Comments (bank material variation, minor inflows, protection extent, etc.):

Right bank protection extends from 25 feet upstream to 0 feet upstream.

Left bank protection extends from 5 feet upstream (where confluence enters) to upstream bridge face.

From 15 feet upstream to the upstream bridge face, the bed material is sand (0\% LB to $40 \% \mathrm{RB})$. 

feet US

(US, UB, DS) positioned 65 \%LB to $\mathbf{8 5} \%$ RB

37. Material: $\mathbf{4 3 2}$

38. Point or side bar comments (Circle Point or Side; Note additional bars, material variation, status, etc.):

This bar is a mid-channel bar with no vegetation.

Another mid-channel bar extends from 32 feet upstream to 15 feet upstream. It is positioned $30 \% \mathrm{LB}$ to $50 \%$ RB, and is comprised of cobbles, gravel, sand as well as vegetation. The bar grades to sand towards the downstream end. At lower flows, these two channel bars could be considered as one point bar.
39. Is a cut-bank present? Y
( $Y$ or if $N$ type ctrl-n $c b)$
40. Where? $\underline{\mathbf{R B}}(L B$ or $R B)$

41. Mid-bank distance: 43

42. Cut bank extent: $\mathbf{6 5}$ eet $\underline{\text { US }}$ (US, UB, DS)

43. Bank damage: 1

(1- eroded and/or creep; 2- slip failure; 3- block failure)

44. Cut bank comments (eg. additional cut banks, protection condition, etc.):

\section{Is channel scour present? $\mathbf{Y}$ (Yor if $N$ type ctrl-n cs) 46. Mid-scour distance: $\mathbf{8}$ UB}
47. Scour dimensions: Length $\mathbf{4 9}$
Width 28
Depth : 1.75
Position 0
$\%$ LB to $100 \%$ RB

48. Scour comments (eg. additional scour areas, local scouring process, etc.):

This scour hole occupies the entire channel width at the mid-scour distance indicated. The scour hole extends from 20 feet upstream to 13 feet downstream. At the mid-scour distance, the scour hole spans across channel, between abutments. The upstream end of the scour hole is situated along the right abutment. The downstream end of the scour hole is positioned in the center of the channel. Average thalweg depth is 0.25 feet.
49. Are there major confluences? Y
( $Y$ or if $N$ type ctrl-n $m c)$
51. Confluence 1: Distance $\frac{\mathbf{5}}{\mathbf{5 5}}$
Confluence 2: Distance
52. Enters on $\underline{\mathbf{L B}}$ (LB or $R B)$
Enters on $\underline{\mathbf{R B}}$ (LB or RB)

50. How many? 2

54. Confluence comments (eg. confluence name):
53. Type 1
(1- perennial; 2- ephemeral)
Type 2 (1- perennial; 2- ephemeral)

Confluence 1 is from a culvert under the TH 2 roadway.

Confluence 2 is a run-off channel which runs along TH 9. It is 3 feet wide and 1.5 feet deep.

\section{Under Bridge Channel Assessment}

55. Channel restraint (BF)? LB $\underline{2}$ (1- natural bank; 2- abutment; 3- artificial levee)

\begin{tabular}{|ccccc}
\hline \multicolumn{2}{|c}{ 56. Height (BF) } & \multicolumn{3}{c}{57 Angle (BF) } \\
LB & RB & LB & RB \\
$\mathbf{2 5 . 5}$ & & & $\mathbf{1 . 0}$ & \\
\hline
\end{tabular}

\begin{tabular}{lc} 
61. Material (BF) \\
LB & RB \\
$\mathbf{2}$ & $\mathbf{7}$ \\
\hline
\end{tabular}
62. Erosion (BF)
LB RB
7
-

58. Bank width (BF) -

59. Channel width (Amb) -

60. Thalweg depth $(\mathrm{Amb}) \quad \mathbf{9 0 . 0}$

63. Bed Material -

Bed and bank Material: 0- organics; 1- silt / clay, < 1/16mm; 2- sand, 1/16 - 2mm; 3- gravel, 2 - 64mm; 4- cobble, 64 - 256mm; 5- boulder, > 256mm; 6- bedrock; 7- manmade

Bank Erosion: 0- not evident; 1- light fluvial; 2- moderate fluvial; 3- heavy fluvial / mass wasting

64. Comments (bank material variation, minor inflows, protection extent, etc.):

324

Abutments are laid-up stone walls with concrete caps.

The streambed is mostly gravel and sand with some cobbles at the thalweg and along the base of each abutments. 
65. Debris and Ice Is there debris accumulation?

(Yor $N)$ 66. Where? $\mathbf{N}$

(1- Upstream; 2- At bridge; 3- Both)

67. Debris Potential ( 1- Low; 2- Moderate; 3- High)

68. Capture Efficiency 1 (1-Low; 2- Moderate; 3- High)

69. Is there evidence of ice build-up? 1 (Y or $N)$

Ice Blockage Potential $\mathbf{N}$

(1- Low; 2- Moderate; 3- High)

70. Debris and Ice Comments:

1

There is significant growth of trees, shrubs, and brush along the immediate banks of this channel. The channel is laterally unstable.

\begin{tabular}{|l|c|c|c|c|c|c|c|c|}
\hline Abutments & $\begin{array}{c}\text { 71. Attack } \\
\angle \mathrm{BF})\end{array}$ & $\begin{array}{c}\text { 72. Slope } \\
(\mathrm{Qmax})\end{array}$ & $\begin{array}{c}\text { 73. Toe } \\
\text { loc. (BF) }\end{array}$ & $\begin{array}{c}\text { 74. Scour } \\
\text { Condition }\end{array}$ & $\begin{array}{c}\text { 75. Scour } \\
\text { depth }\end{array}$ & $\begin{array}{c}\text { 76. Exposure } \\
\text { depth }\end{array}$ & 77. Material & 78. Length \\
\hline LABUT & & $\mathbf{1 5}$ & $\mathbf{9 0}$ & $\mathbf{2}$ & $\mathbf{1}$ & $\mathbf{0 . 7 5}$ & $\mathbf{0}$ & $\mathbf{9 0 . 0}$ \\
\hline RABUT & $\mathbf{2}$ & - & $\mathbf{9 0}$ & & & $\mathbf{2}$ & $\mathbf{1}$ & $\mathbf{2 6 . 0}$ \\
\hline
\end{tabular}

Pushed: $L B$ or RB

Toe Location (Loc.): 0- even, 1- set back, 2- protrudes

Scour cond.: 0- not evident; 1- evident (comment); 2- footing exposed; 3-undermined footing; 4- piling exposed; 5- settled; 6- failed

Materials: 1- Concrete; 2- Stone masonry or drywall; 3- steel or metal; 4- wood

79. Abutment comments (eg. undermined penetration, unusual scour processes, debris, etc.):

0.75

0

2

Scour exists along the LABUT for the entire base length.

On the RABUT, scour is present only along the upstream half of the abutment.

80. Wingwalls:

Exist? Material? Scour Scour Exposure 81. Condition? depth? depth?

USLWW:

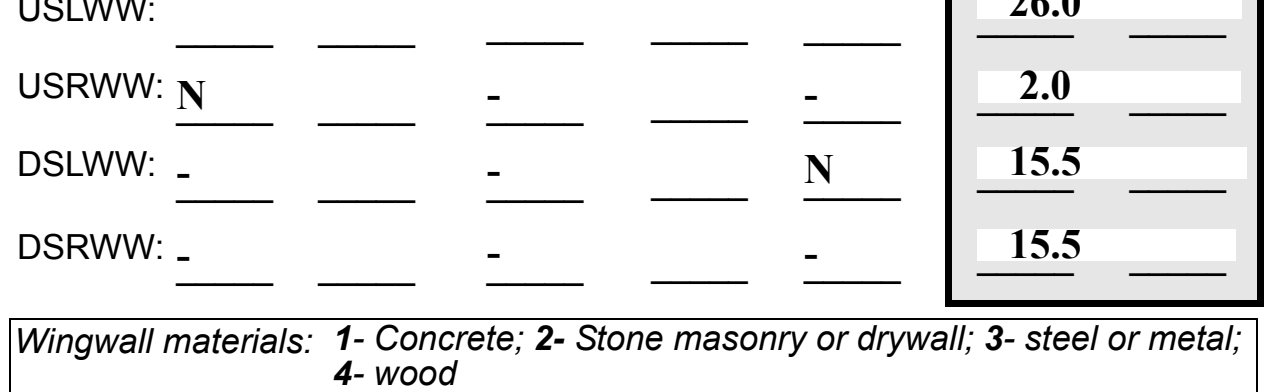

Wingwall materials: 1- Concrete; 2- Stone masonry or drywall; 3- steel or metal; 4- wood

26.0

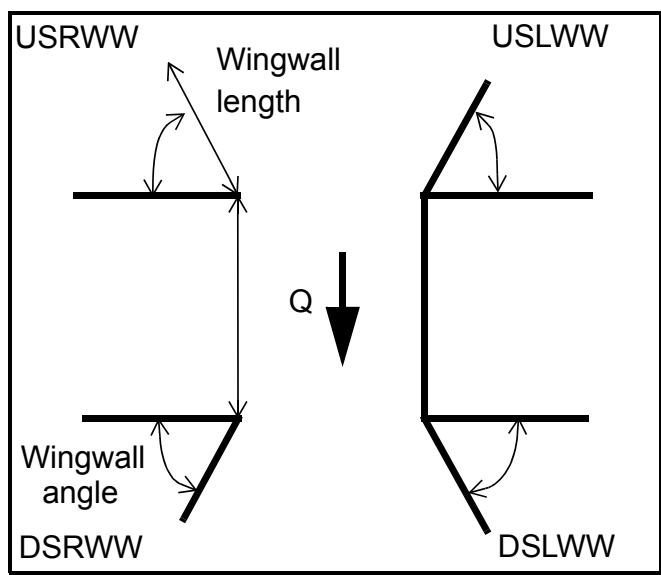

82. Bank / Bridge Protection:

\begin{tabular}{|l|l|l|l|l|l|l|l|l|}
\hline Location & USLWW & USRWW & LABUT & RABUT & LB & RB & DSLWW & DSRWW \\
\hline Type & - & - & N & - & - & - & - & - \\
\hline Condition & $\mathbf{N}$ & - & - & - & - & - & - & - \\
\hline Extent & - & - & - & - & - & $\mathbf{0}$ & $\mathbf{0}$ & - \\
\hline
\end{tabular}

Bank / Bridge protection types: 0- absent; 1- < 12 inches; 2- < 36 inches; 3- < 48 inches; 4- < 60 inches; 
83. Wingwall and protection comments (eg. undermined penetration, unusual scour processes, etc.):

-
-
-
-
-
-
-
-

\section{Piers:}

84. Are there piers? _ _ (Y or if $N$ type ctrl-n pr)

\begin{tabular}{|l|l|l|l|l|l|l|l|}
\hline \multirow{2}{*}{$\begin{array}{l}85 . \\
\text { Pier no. }\end{array}$} & \multicolumn{3}{|c|}{ width (w) feet } & \multicolumn{3}{c|}{ elevation (e) feet } \\
\cline { 2 - 9 } & w1 & w2 & w3 & e@w1 & e@w2 & e@w3 \\
\hline Pier 1 & - & - & - & - & - & - \\
\hline Pier 2 & - & - & - & - & - & - \\
\hline Pier 3 & - & - & - & - & - & - & - \\
\hline Pier 4 & - & - & - & - & - & w1 \\
\hline
\end{tabular}

\begin{tabular}{|l|l|l|l|l|}
\hline Level 1 Pier Descr. & 1 & \multicolumn{1}{|c|}{2} & 3 & \multicolumn{1}{|c|}{} \\
\hline 86. Location (BF) & & - & - & - \\
\hline 87. Type & & - & - & - \\
\hline 88. Material & & - & - & - \\
\hline 89. Shape & & - & - & - \\
\hline 90. Inclined? & & - & - & - \\
\hline 91. Attack $\angle$ (BF) & & - & - & - \\
\hline 92. Pushed & & - & - & - \\
\hline 93. Length (feet) & - & - & - & - \\
\hline 94. \# of piles & & - & - & - \\
\hline 95. Cross-members & & - & - & - \\
\hline 96. Scour Condition & & - & - & - \\
\hline 97. Scour depth & $\mathbf{N}$ & - & - & - \\
\hline 98. Exposure depth & - & - & - & - \\
\hline
\end{tabular}

LFP, LTB, LB, MCL, MCM, MCR, RB, RTB, RFP

1- Solid pier, 2- column, 3- bent

1-Wood; 2- concrete; 3- metal; 4- stone

1- Round; 2- Square; 3- Pointed

Y-yes; $N$ - no

$L B$ or $R B$

0- none; 1- laterals; 2- diagonals; 3- both

0- not evident; 1- evident (comment);

2- footing exposed; 3- piling exposed;

4- undermined footing; 5- settled; 6- failed 
99. Pier comments (eg. undermined penetration, protection and protection extent, unusual scour processes, etc.):

-
-
-
-
-
-
-
-
-
-

100.

\section{E. Downstream Channel Assessment}

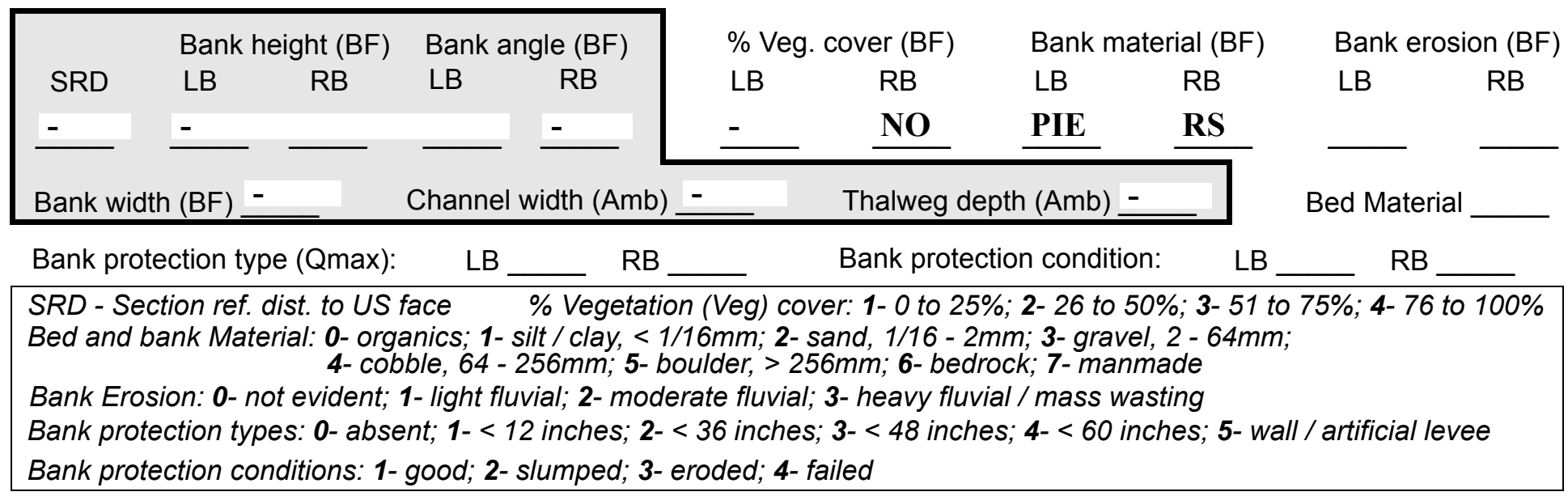

Comments (eg. bank material variation, minor inflows, protection extent, etc.):

2
2
24
24
1
1
342
2
0
1
-

Left bank protection extends from 0 feet downstream to 20 feet downstream.

101. Is a drop structure present? ___ ( $Y$ or $N$, if $N$ type ctrl-n ds) 102. Distance: ___ feet
103. Drop: - feet
104. Structure material:
(1- steel sheet pile; 2- wood pile; 3-concrete; 4- other)

105. Drop structure comments (eg. downstream scour depth): 
106. Point/Side bar present? (Y or N. if $N$ type ctrl-n pb)Mid-bar distance: Mid-bar width:

Point bar extent: feet

(US, UB, DS) to $\underline{\mathbf{N}}$ feet (US, UB, DS)

DS) positioned $\%$ LB to $\underline{\text { DR }} \%$ RB

Material: $\mathbf{O P}$

Point or side bar comments (Circle Point or Side; note additional bars, material variation, status, etc.):

\section{STRUCTURE}

Is a cut-bank present? ( $Y$ or if $N$ type ctrl-n $c b) \quad$ Where? (LB or $R B)$

Mid-bank distance: $\underline{\mathbf{Y}}$ Cut bank extent: $\underline{\mathbf{3 4}}$ feet $\underline{\mathbf{1 0}}$ (US, UB, DS) to $\underline{\mathbf{2 5}}$ feet $\underline{\mathrm{DS}}$ (US, UB, DS)

Bank damage: 42 (1-eroded and/or creep; 2- slip failure; 3- block failure)

Cut bank comments (eg. additional cut banks, protection condition, etc.):

DS

0

30

324

Is channel scour present? Th ( $Y$ or if $N$ type ctrl-n cs) Mid-scour distance: $\underline{\mathbf{e}}$ Scour dimensions: Length abov Width e Depth: $\underline{\text { dim }} \quad$ Positioned ensi \% $\%$ LB to ons $\%$ RB Scour comments (eg. additional scour areas, local scouring process, etc.):

are for a side bar, which is vegetated at the upstream end.

Another side bar extends from 39 feet downstream to 51 feet downstream. It is positioned from $75 \%$ LB to $100 \% \mathrm{RB}$. The mid-bar distance is 43 feet downstream, where it is $\mathbf{4 3}$ feet wide. The bar is composed of gravel, sand and cobbles, and it is vegetated along the upstream and streamward edge.

Are there major confluences? $\mathbf{Y}$ (Y or if $N$ type ctrl-n $m c) \quad$ How many? $\underline{\mathbf{R B}}$

Confluence 1: Distance $\underline{15}$ Enters on $\underline{\mathbf{0}}$ (LB or RB) Type $\underline{\mathbf{D S}}$

(1- perennial; 2- ephemeral)

Confluence 2: Distance 21

Enters on $\underline{\text { DS }}$ (LB or RB)

Type 1 (1- perennial; 2- ephemeral)

Confluence comments (eg. confluence name):

Another cut-bank is on the left bank from 40 feet downstream to 56 feet downstream. Mid-bank distance is 48 feet. Bank is eroded, as well as undermined.

\section{F. Geomorphic Channel Assessment}

107. Stage of reach evolution

1- Constructed

2- Stable

3- Aggraded

4- Degraded

5- Laterally unstable

6- Vertically and laterally unstable 
108. Evolution comments (Channel evolution not considering bridge effects; See HEC-20, Figure 1 for geomorphic descriptors):

Y

Scour is described in \#45.

$\mathbf{N}$ 


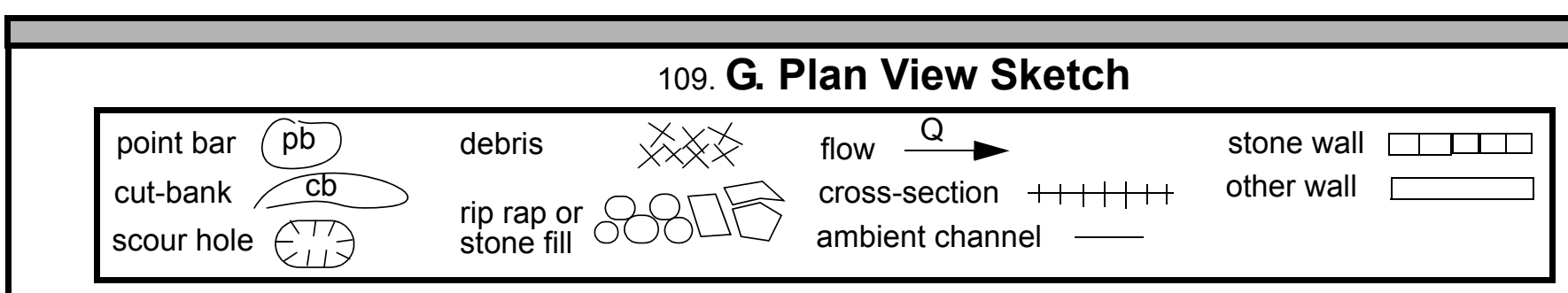


APPENDIX F:

SCOUR COMPUTATIONS 


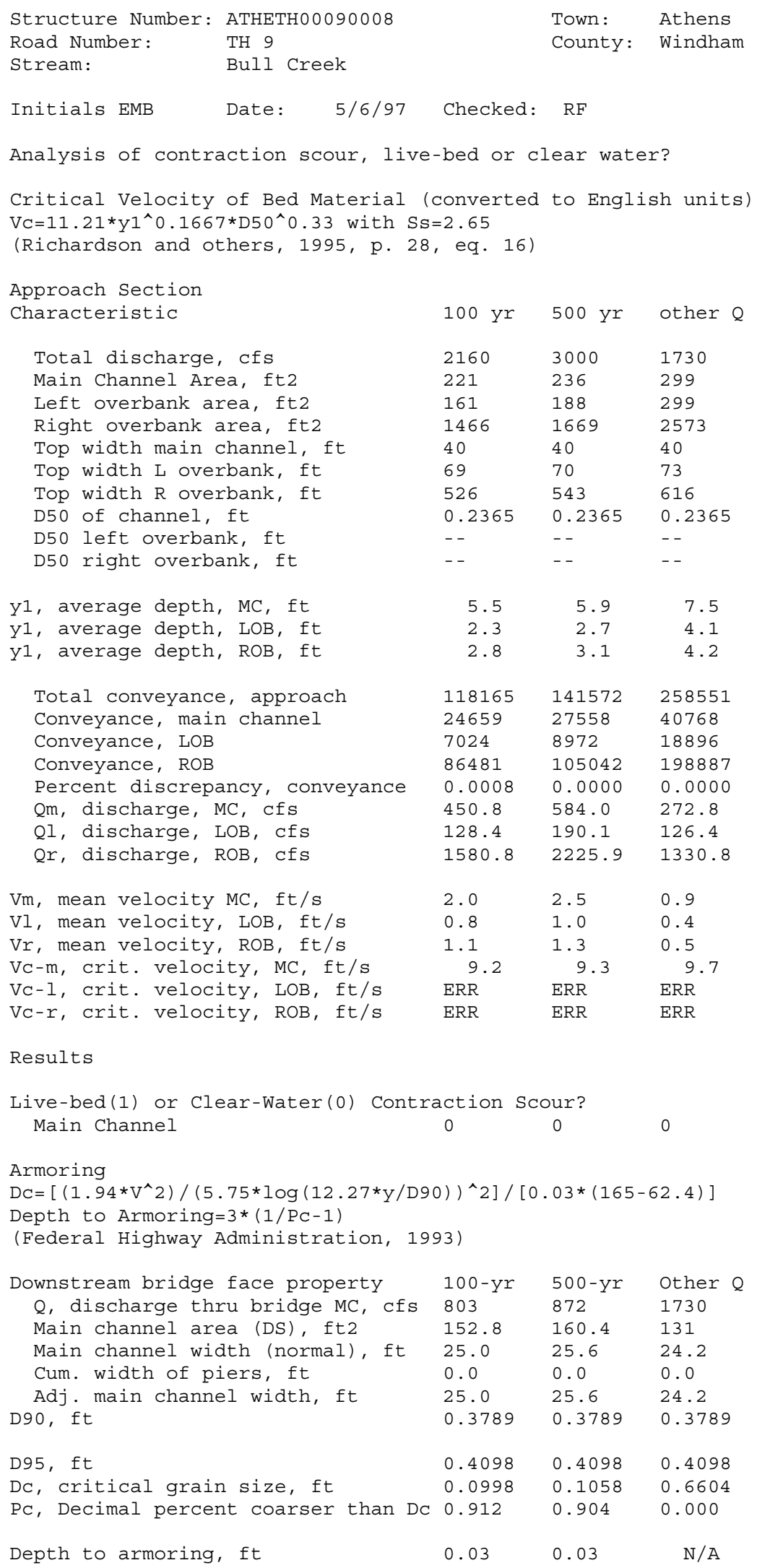


Clear water Contraction Scour in MAIN CHANNEL

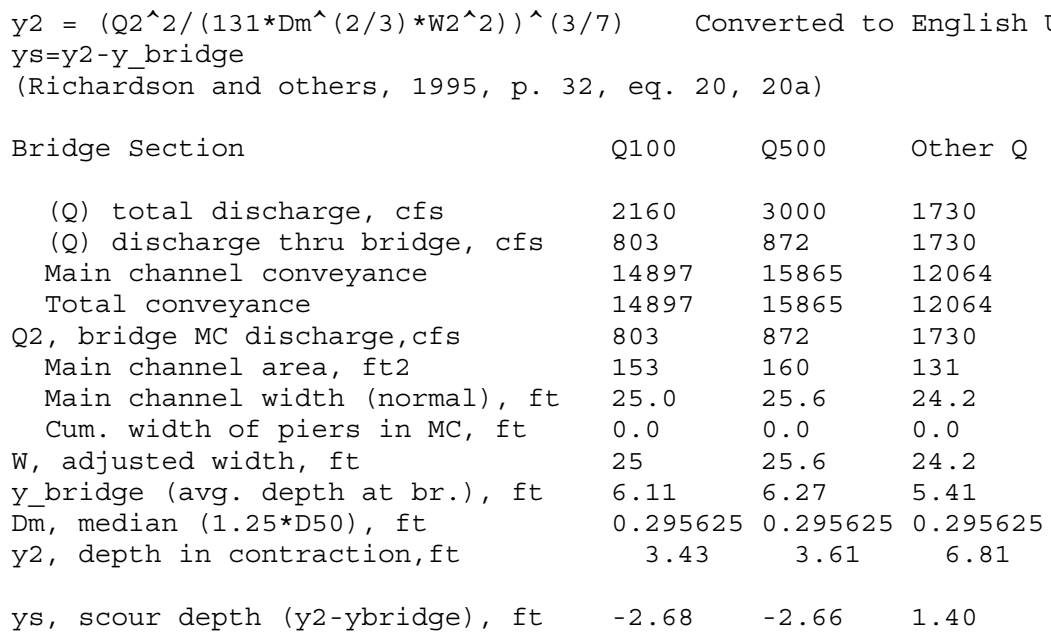

Abutment scour

Froehlich's Abutment Scour

$\mathrm{Ys} / \mathrm{Y} 1=2.27 * \mathrm{~K} 1 * \mathrm{~K} 2 *\left(\mathrm{a}^{\prime} / \mathrm{Y} 1\right)^{\wedge} 0.43 * \mathrm{Fr} 1 \wedge 0.61+1$

(Richardson and others, 1995, p. 48, eq. 28)

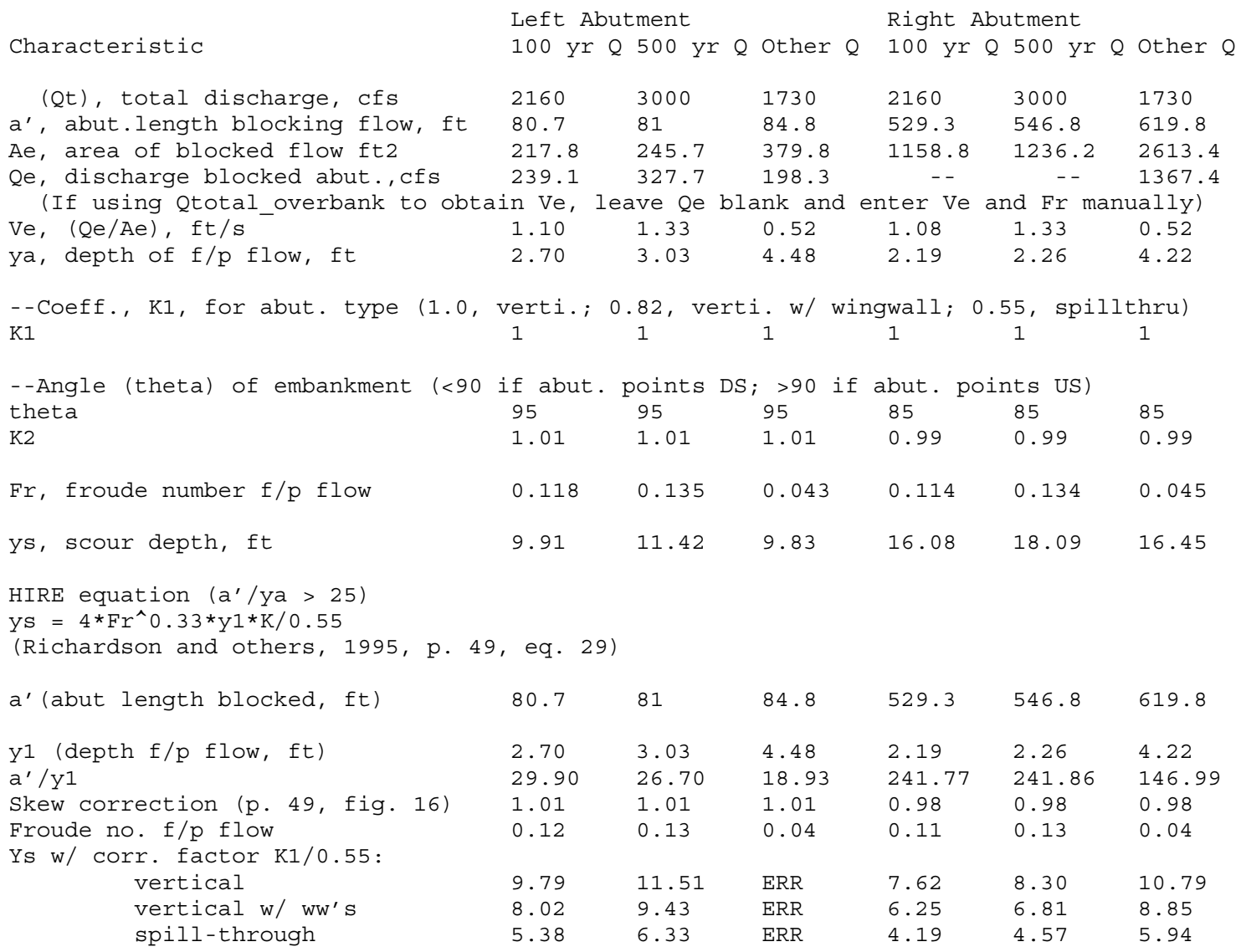


Abutment riprap sizing

Isbash Relationship

$\mathrm{D} 50=\mathrm{Y} * \mathrm{~K} * \mathrm{Fr}^{\wedge} 2 /(\mathrm{Ss}-1)$ and $\mathrm{D} 50=\mathrm{Y} * \mathrm{~K} *\left(\mathrm{Fr}^{\wedge} 2\right)^{\wedge} 0.14 /(\mathrm{Ss}-1)$

(Richardson and others, 1995, p112, eq. 81,82)

Downstream bridge face property

Q100 Q500

$0.52 \quad 0.53$

Fr, Froude Number

$6.11 \quad 6.27$

Other

Q100

Q500

Other Q

$y$, depth of flow in bridge, ft

6.27

1

5.41

0.52

0.53

6.11

6.27

1

Median Stone Diameter for riprap at: left abutment

right abutment, ft

Fr<=0.8 (vertical abut.)

$1.02 \quad 1.09$

Fr>0.8 (vertical abut.)

ERR

1.09
ERR

ERR

ERR
2.26

1. 02

1.09

ERR

ERR

ERR

2.26 